\title{
Laços familiares e aspectos materiais da dinâmica mercantil na cidade de São Paulo (séculos XVIII e XIX)
}

\begin{abstract}
Maria Aparecida de Menezes Borrego ${ }^{2}$
RESUMO: A partir das relações familiares estabelecidas no seio do grupo mercantil ativo na cidade de São Paulo ao longo dos séculos XVIII e XIX, pretende-se narrar as trajetórias de vida de nove agentes comerciais envolvidos nas alianças matrimoniais, destacando os negócios realizados, a atuação sociopolítica e o encaminhamento dado aos descendentes. Em seguida, busca-se articular o desenvolvimento urbano do centro da capital com a atuação destes homens de negócio, concentrando as análises sobre aspectos da vida material relacionados às suas moradias e ao mobiliário existente no espaço doméstico.

PALAVRAS-ChAVE: Comércio. Relações de parentesco. Transmissão de fortunas. Mobiliário. Espaço doméstico. São Paulo (cidade).

ABSTRACT: Based on the family ties established within the active merchant community of the city of São Paulo through the $18^{\text {th }}$ and $19^{\text {th }}$ centuries, the author sets out to tell the life story of nine merchants involved in matrimonial alliances, with a focus on the transactions carried out, their sociopolitical engagement and the fortunes of their descendants. Having done that, she seeks out connections between the urban development of the city center and the activities of these businessmen by means of analyses centered on the material aspects of their lives, particularly those related to their homes and home furniture.

KEYWORDS: Trade. Family relations. Transmission of wealth. Furniture. Domestic space. São Paulo (city).
\end{abstract}

Introdução

Durante décadas prevaleceu, na produção historiográfica, a ideia da cidade - e da capitania - de São Paulo isolada, pobre e decadente no período
1. Este artigo apresenta resultados parciais da pesquisa de pós-doutorado, em andamento no Museu Paulista da Universidade de São Paulo, acerca das relações entre comércio e sociedade na cidade de São Paulo entre 1765 e 1809. Articulados às linhas de pesquisa da instituição, Cotidiano e sociedade e Universo do trabalho, três eixos orientam a investigação: as atividades econômicas e sociopolíticas, as relações familiares e aspectos da vida material do grupo mercantil residente na capital paulista. Sobre as linhas de pesquisa do Museu Paulista, ver Ulpiano T. B. de Meneses (1992) e Cecília Helena de S. Oliveira (2005).

2. Pesquisadora do programa de pós-doutorado do Museu Paulista da Universidade de São Paulo; bolsista Fapesp. E-mail: maborrego@terra. com.br. Projeto de pesquisa intitulado Comércio e sociedade: práticas, vivências $e$ fortunas na cidade de São Paulo (1765-1809), sob supervisão da Prof. ${ }^{a}$ Dr. ${ }^{a}$ Cecília Helena de Salles Oliveira. 
3. São expoentes deste viés interpretativo Paulo Prado (2004); Afonso de E. Taunay (1923); Caio Prado Junior (1975); Alfredo Ellis Junior (1950); Maria Thereza S Petrone (1968); e Alice P. Canabrava (1972).

4. Ao longo do texto, as palavras "paulistano" e "piratiningano" são utilizadas como relativas à cidade de São Paulo e a seus habitantes; da mesma forma, "paulista" se refere à capitania e/ou província de São Paulo e aos seus habitantes. Ainda que por vezes extemporâneos ao contexto estudado, os vocábulos foram eleitos para evitar a repetição excessiva da expressão "de São Paulo".

5. Cf. Maria Luiza Marcílio (1974).

6. Ver Maria Luiza Marcílio (2000). O ano de 1765 corresponde à data de restauração da capitania, subordinada ao Rio de Janeiro durante dezessete anos, e ao retorno da cidade de São Paulo ao posto de capital. Sob o governo de D. Luis Antonio de Souza Botelho Mourão, o Morgado de Mateus, a população passou a ser alvo das diretrizes da política pombalina que tinha como objetivos a militarização, a exploração territorial, a urbanização, o estímulo para a produção agrícola de exportação e a dinamização do comércio. Sobre os motivos para a restauração da capitania e as instruções de governo do Morgado, ver Heloísa L. Bellotto (2007).

7. Ver Elizabeth Darwiche Rabelo (1980).

8. Ver Kátia Maria Abud (1978).

9. Ver Elizabeth Anne Kuznesof (1980).

10. Ver Francisco Vidal Luna e Herbert Klein (2005). setecentista. Segundo diversos autores, tais imagens justificavam-se pela ausência de produtos agrícolas de exportação. Com base nesta argumentação, somente no início do oitocentos, assentada na produção comercial de açúcar e, posteriormente de café, a região passaria a integrar as rotas do mercado atlântico ${ }^{3}$.

Entretanto, a partir dos anos 1960 e nas décadas seguintes, pesquisas acadêmicas dedicadas à análise da sociedade e da economia paulistas ${ }^{4}$ na segunda metade do século XVIII, trouxeram novas interpretações, embasadas principalmente nos dados extraídos dos recenseamentos ocorridos na capitania desde 1765 .

Maria Luiza Marcílio ressaltou o aumento demográfico contínuo vivenciado pela cidade de São Paulo e a importância do setor terciário na composição da população e na própria definição do caráter mercantil urbano ${ }^{5}$. Além disso, destacou o papel significativo desempenhado pela produção agrícola para o abastecimento das regiões mineradoras na montagem da agricultura comercial canavieira voltada ao mercado externo, implementada a partir do governo do Morgado de Mateus ${ }^{6}$. Elizabeth Darwiche Rabelo constatou a presença de negociantes no topo da hierarquia social, ao lado das elites dirigentes - senhores de engenho e alto clero - e a diversificação das atividades mercantis decorrentes dos negócios do açúcar? . Kátia Maria Abud verificou a ascensão política e social de comerciantes reinóis e sua forte inserção nos órgãos de poder local ${ }^{8}$. Elizabeth Anne Kuznesof examinou a responsabilidade do grupo mercantil na implantação de uma infraestrutura comercial, promotora do dinamismo econômico da São Paulo setecentista?

Mais recentemente, Francisco Vidal Luna e Herbert Klein publicaram uma pesquisa de fôlego sobre a estrutura da posse de escravos em várias localidades paulistas, entre 1750 e 1850. Para além dos resultados instigantes sobre a diversidade produtiva nas unidades açucareiras e cafeicultoras, os estudiosos destacaram uma significativa minoria da população que não se dedicava à lide agrícola. Tal parcela teria aumentado ao longo dos anos, conforme a economia e a sociedade foram se tornando mais complexas e mais urbanas.

Embora heterogênea, ela comportava elementos realmente abastados, detentores de muitos cativos - como os comerciantes com negócios internacionais e os tropeiros com grandes tropas de mulas e escravos - que viviam na cidade de São Paulo. Esse grupo compunha a elite não agrícola e, juntamente com os agricultores mais ricos de açúcar e café, representavam a classe dominante da sociedade provincial da primeira metade do século XIX10.

Em poucas palavras, os pesquisadores que se debruçaram sobre a realidade socioeconômica paulista em fins do período colonial, a partir da análise dos maços de população, não só colocaram em xeque o isolamento, a pobreza e a decadência da capitania, como salientaram a importância dos comerciantes no conjunto da população, em especial na cidade de São Paulo, a partir de 1765.

O desenvolvimento do comércio na capital, durante o setecentos, também figuraria no estudo de Muriel Nazzari sobre a prática do dote e seu 
gradual desaparecimento na sociedade paulistana entre 1600 e 1900, a partir do trabalho exaustivo com inventários ${ }^{11}$.

Embora verificasse que muitos comerciantes bem-sucedidos se casaram no seio das famílias paulistas tradicionais, a historiadora alertou para o fato de as transações comerciais terem possibilitado o enriquecimento de seus agentes, que, para se estabelecer, puderam dispensar tanto o dote de suas esposas como as uniões com a elite agrária, para ocupar postos militares e políticos, alcançados, cada vez mais, por meio da riqueza acumulada. Ou seja, se antes eram os comerciantes que procuravam estabelecer alianças matrimoniais com a elite agrária, a fim de ascender social e economicamente, a partir de meados dos setecentos, a situação se inverteria, pois os proprietários de terra passaram a cobiçar genros comerciantes, com vistas a partilhar as fortunas amealhadas.

Ao analisar alguns casos de transmissão de fortunas do grupo mercantil para os descendentes, a historiadora detectou que a continuidade dos negócios ficava a cargo dos genros, enquanto os filhos varões eram encaminhados para a carreira eclesiástica e militar, para a realização dos estudos em Coimbra e para o casamento com filhas da elite agrária.

A grande contribuição do estudo de Nazzari para a discussão aqui esboçada acerca da realidade paulistana setecentista curiosamente foi a opção de tratar o tema na longa duração. Por não eleger meados do século XVIII como baliza inicial da pesquisa, a historiadora teve a possibilidade de avaliar as continuidades existentes entre a primeira e a segunda metade dos setecentos e perceber a presença do comerciante na cidade de São Paulo desde as décadas iniciais da centúria e não apenas a partir da restauração da capitania e da implementação da política pombalina.

Analisar a atuação do grupo mercantil na capital paulista no contexto anterior à chegada do Morgado de Mateus, com especial atenção à participação dos agentes comerciais nos órgãos de poder local, foi o principal objetivo perseguido em minha pesquisa de doutorado ${ }^{12}$.

A tese evidenciou que, até o terceiro quartel do século XVIII, o grupo mercantil atuante na cidade de São Paulo era formado sobretudo por reinóis que, ainda adolescentes, partiram das terras de origem em direção à América portuguesa. Antes da residência definitiva em solo paulistano, muitos permaneceram na cidade do Rio de Janeiro ou percorreram localidades de Minas Gerais, Mato Grosso e Goiás, ligadas à mineração, onde foram introduzidos no mundo do comércio. Uma vez estabelecidos na cidade de São Paulo, passaram a dedicar-se a múltiplas atividades econômicas. Para além das lojas de fazenda seca, os comerciantes dispunham de escravos vendeiros e negras padeiras; estavam envolvidos direta ou indiretamente com os contratos camarários, relativos ao abastecimento alimentar da população; estabeleciam lojas e firmavam sociedades em outras localidades; comercializavam escravos em várias áreas coloniais; traziam carregações do Rio de Janeiro e as enviavam para as regiões mineradoras; emprestavam dinheiro a juros. Todos os negócios permeados por dívidas que uniam e prolongavam relações mercantis e pessoais.
11. Ver Muriel Nazzari (2001).

12. Ver Maria Aparecida de Menezes Borrego (2010). 
13. Ver Benedito L. de Toledo (2004).

14. Esta constatação reitera as análises sobre as relações familiares entre comerciantes empreendidas por Jorge M. V. Pedreira (1995), para os homens de negócio da praça de Lisboa; de Susan Socolow (1991), para os mercadores de Buenos Aires; de Helen Osório (2007), para o segmento mercantil do Rio Grande do Sul; e de Rae J. D. Flory (1978), para os comerciantes na Bahia.
Os agentes residiam sobretudo na Sé e concentravam-se na área mais central do espaço urbano, o chamado Triângulo, formado pelas ruas Direita, São Bento e Rosário (atualmente 15 de Novembro). Os vértices do Triângulo, à beira de terrenos escarpados, eram ocupados pelos edifícios religiosos mais importantes daquele tempo - São Bento, São Francisco e Carmo. As ruas Direita e São Bento cortavam-se no cruzamento denominado Quatro Cantos, onde, no período colonial, construíam-se arcos enfeitados para recepcionar autoridades eclesiásticas e civis, e de onde partiam os desfiles de andores pela rua Direita em direção ao Pátio do Colégio, local que, após a expulsão dos jesuítas, sediou - Palácio do Governador. No decorrer do século XIX, tal entroncamento vai continuar gozando de prestígio, como ponto de encontro de procissões na Semana Santa e local da reza pública do terço, face a um nicho com a imagem de Santo Antonio ${ }^{13}$.

Os estabelecimentos comerciais - lojas de fazenda seca, vendas e tavernas - e os negócios empreendidos trouxeram nova vida à urbe, modificando a paisagem física e humana da cidade de São Paulo e suas cercanias ao longo do século XVIII. Se, nos séculos anteriores, os moradores residiam, em geral, nos arredores e só se dirigiam à cidade quando tinham questões a resolver, os portugueses dedicados ao comércio adotaram comportamento diverso. Preferindo fixar habitação e instalar lojas no centro da capital, não mais encararam o espaço urbano como apêndice do campo, mas, sim, como centro mercantil em desenvolvimento, espaço privilegiado para a realização das atividades econômicas, favorável às possibilidades de ascensão social, à participação nas instituições de prestígio e às alianças matrimoniais.

O alto índice de comerciantes casados mostrou que a opção pelo matrimônio procurava concretizar múltiplas expectativas, entre elas, o fortalecimento da carreira mercantil, a aquisição de fortuna e a conquista de projeção social. Embora até meados do século XVIII a origem do corpo comercial fosse externa à capitania de São Paulo e à própria colônia, as esposas escolhidas eram naturais da terra, em geral nascidas na própria cidade e nas vilas vizinhas. Se muitos que aqui chegaram no alvorecer do século XVIII se uniram às famílias da terra, outros tantos, vindos depois, acabaram por contrair núpcias com filhas, netas e sobrinhas de portugueses já residentes e conhecidos na praça, perpetuando, por gerações, as práticas de casamentos endogâmicos ${ }^{14}$.

Relações familiares e trajetórias de vida no mundo dos negócios

Tomando as relações de parentesco como fio de condutor da análise, os resultados parciais da pesquisa de pós-doutorado são aqui expostos a partir da narração das trajetórias de vida de nove agentes mercantis, cujas famílias, por 
meio de matrimônios, começaram a entrelaçar-se desde a primeira metade do século XVIII e continuaram a unir-se até o século seguinte, na geração falecida na década de 1870. A atenção recai principalmente nos negócios realizados, na atuação sociopolítica e nos aspectos da vida material relacionados às residências urbanas e ao mobiliário existente no espaço doméstico de Manuel Veloso (1667-1752), Manuel Mendes de Almeida (2̣-1754), Manuel José da Cunha (2-1746), José Rodrigues Pereira (1703-1770), Francisco Pereira Mendes (1710-1781), Manuel Rodrigues Jordão (alferes) (1727-1785), Manuel Rodrigues Jordão (brigadeiro) (1780-1827), Joaquim Mariano Galvão de Moura Lacerda (2-1834), Joaquim José dos Santos (1747-1828)15. Como se vê, as existências dos sujeitos selecionados extrapolam as balizas cronológicas da investigação em curso no Museu Paulista, mas, pelas relações familiares e pelas atividades econômicas a que se dedicavam, estão articuladas.

Contudo, antes de descrever os percursos trilhados pelos personagens, é fundamental esclarecer os procedimentos adotados para a montagem do diagrama apresentado (Figura 1). Em primeiro lugar, enfatiza-se que a "árvore genealógica", de cunho artesanal, foi elaborada para atender às finalidades do atual estágio da investigação, ou seja, para facilitar a visualização dos matrimônios contraídos no seio do grupo comercial, aprofundando laços internos e consolidando interesses econômicos.

diagrama envolveu as relações familiares dos agentes mercantis citados e alguns de seus descendentes, privilegiando-se a exposição das linhagens dos homens ligados ao comércio e que estabeleceram alianças matrimoniais entre as citadas famílias. Quando os nomes ou sobrenomes dos indivíduos encontrados nos documentos diferiram dos apresentados nas obras genealógicas, optou-se pela manutenção daqueles registrados nas fontes.

Passemos, então, a acompanhar os movimentos de membros dos grupos familiares escolhidos.

Embora não se saiba quando Manuel Veloso, proveniente do arcebispado de Braga, chegou a São Paulo, é certo que já residia aí desde a primeira década do século XVIII'16. Durante toda a vida, sua participação na deliberação de vários assuntos importantes aos paulistanos foi ativa ${ }^{17}$. Nos órgãos de poder local, atuou como capitão das ordenanças ${ }^{18}$, almotacé na Câmara Municipal ${ }^{19}$ e procurador na Irmandade do Santíssimo Sacramento da Sé ${ }^{20}$. Até o final de sua existência, esteve atrelado à lide comercial e, ao morrer octogenário, em 1751, residia numa morada de casas situada na rua Direita, de dois lanços e seus corredores, cobertas de telhas e revestidas com paredes de pilão ${ }^{21}$.

Era possuidor, ainda, de dois sítios localizados nos arredores da capital, 72 cabeças de gado e 17 escravos, distribuídos pela cidade e pela roça. No inventário, entretanto, não houve menção à sesmaria de uma légua e meia de terra, em quadra junto ao rio Camapoã, solicitada em 1728, com a justificativa
15. A documentação consultada raramente trouxe as datas de nascimento e/ou batismo dos personagens em tela. Portanto, os anos referentes ao nascimento, quando aparecem entre parênteses, muitas vezes foram obtidos a partir do cruzamento de informações presentes em diversos corpos documentais que forneceram dados para cálculo. É importante, pois, considerá-las datas aproximadas.

16. No ano de 1709 , Veloso foi convocado pelos oficiais da Câmara Municipal de São Paulo a deliberar sobre o ajuste do preço do sal, Cf. Actas da Camara Municipal de S. Paulo, 8. São Paulo: Typographia Piratininga, 1916. p. 187-189.

17. Cf. Actas da Camara Municipal de S. Paulo, 9. São Paulo: Typographia Piratininga, 1916. p. 21-22, 79-80, 174-175; Actas da Camara da Cidade de S. Paulo, 10 São Paulo: Typographia Piratininga, 1916. p. 86-87, 363-365, 370-372, 462-464, 484-485; Actas da Camara Municipal de S. Paulo, 11. São Paulo: Typographia Piratininga, 1916. p. 183-185.

18. Cf. Registo Geral da Camara Municipal de S. Paulo, 4. São Paulo: Typographia Piratininga, 1917. p. 268-270.

19. Cf. Actas da Camara Municipal de S. Paulo, 9 São Paulo: Typographia Piratininga, 1916. p. 490-491.

20. Ver Livro das eleições $e$ dos inventários da fábrica da Irmandade do Santíssimo Sacramento, no Arquivo da Cúria Metropolitana de São Paulo.

21. Ver o registro relativo a Manuel Veloso, no Arquivo do Estado de São Paulo, Juízo Ordinário. Inventários e testamentos, C00528-1752. 


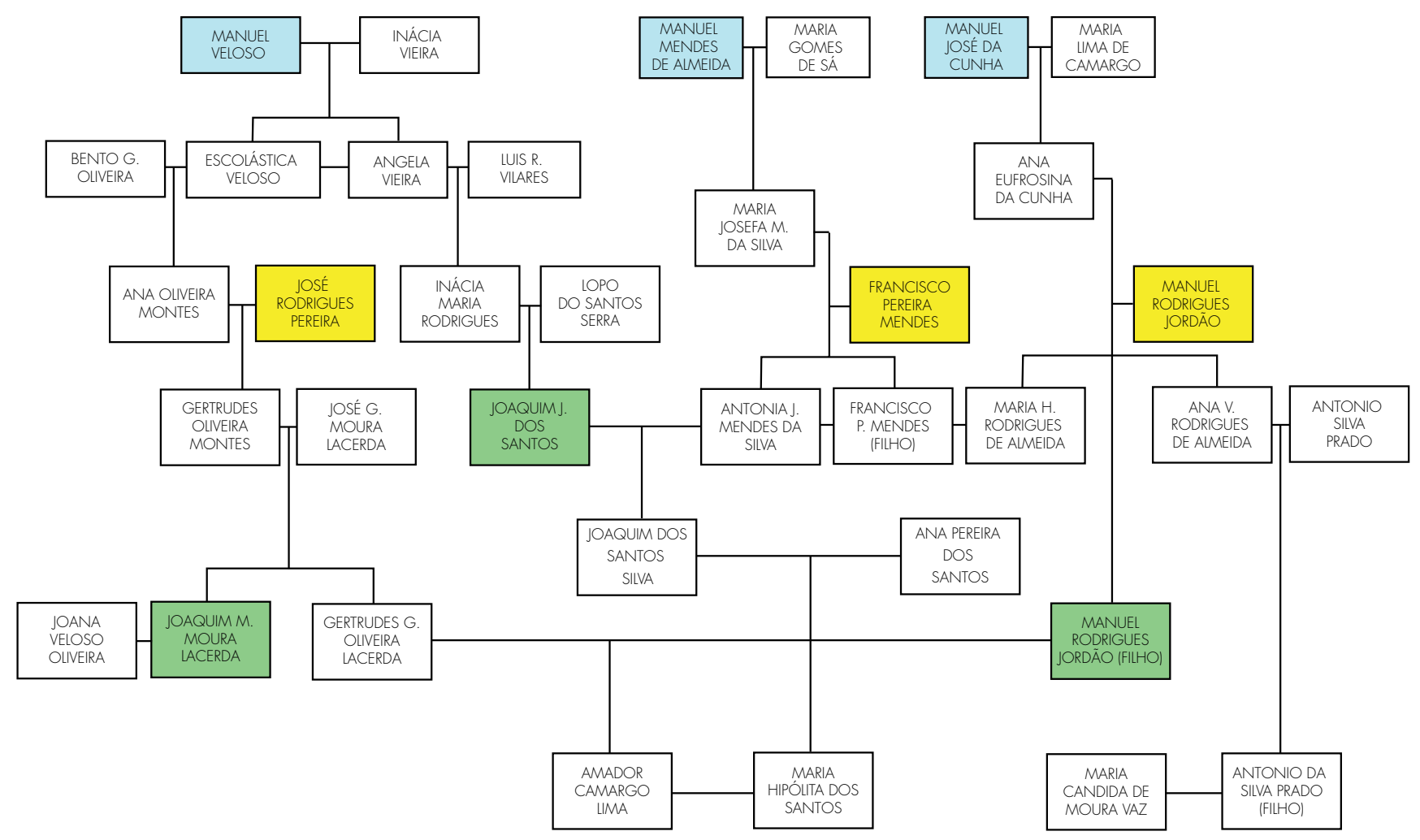

Geração falecida nas décadas de 1740-1750

Geração falecida nas décadas de 1760-1780.

Geração falecida nas décadas de 1820-1830

Figura 1 - Relações de parentesco entre famílias de agentes comerciais atuantes na cidade de São Paulo (séculos XVIII e XIX)

Fontes: Actas da Camara Municipal de S. Paulo (vols. 8 ao 13); Registo Geral da Camara Municipal de S. Paulo (vol. 4); Anais da Biblioteca Nacional (vol. 62); Documentos interessantes para a história e costumes de São Paulo (vol. 62); Instituto dos Arquivos Nacionais da Torre do Tombo - Habilitações da Ordem de Cristo; Arquivo do Estado de São Paulo - Inventários e testamentos; AESP - Maço de população (1798); Arquivo do Tribunal de Justiça do Estado de São Paulo - Inventários do 1ำ cartório da família; Arquivo da Cúria Metropolitana de São Paulo (ACMSP) Dispensas e processos matrimoniais; ACMSP - Registros de casamento; ACMSP - Livro das eleições e dos inventários da fábrica da lrmandade do Santíssimo Sacramento; ORTMANN (1951); LEME (1980), LEME (2002), MARQUES (1954) e BROTERO (1954).

22. Ver, no Arquivo do Estado de São Paulo, Sesmarias, patentes e provisões, livro 2 , f. $142 \mathrm{v}$.

23. Cf. o volume 8 de Luiz Gonzaga da S. Leme (2002, p. 322-323). de fabricar uma fazenda de gado vacum e cavalos, e roças de mantimentos, para atender aos mineradores que se dirigiam às minas de Cuiabá22.

Seu patrimônio bruto, avaliado em cerca de 12 contos de réis, era encabeçado pelas dívidas ativas, com devedores espalhados pelas minas de Cuiabá, Goiás e Paranapanema. Paralelamente aos negócios e à participação sociopolítica na vida cotidiana da cidade, Veloso se casou com Inácia Vieira e constituiu família. Embora se desconheça a ocupação de Francisco Vieira Antunes, seu sogro, os dados genealógicos indicam que o português estava unido a uma família da terra ${ }^{23}$. 
Manuel Mendes de Almeida, originário da vila de Figueiró dos Vinhos, bispado de Coimbra, já se encontrava na freguesia de Monteserrate de Cotia, casado com Maria Gomes de Sá, na década de 1720, quando, juntamente com o sogro Manuel Gomes de Sá, solicitou uma sesmaria em Caucaia ${ }^{24}$, ali cultivando milho e feijão, criando porcos e dispondo de alguns poucos cavalos de carga para a condução dos mantimentos.

Embora tivesse permanecido nessa freguesia até o final da vida, morando na propriedade herdada da sogra Felícia da Silva, era também proprietário de uma morada de casas junto aos Quatro Cantos, no coração da cidade de São Paulo. Vizinhas a tal residência, ficavam uma loja de mercador e uma loja de tabuado, localizadas na rua Direita ${ }^{25}$. Além do comércio de fazenda seca, esteve envolvido com negócios mal sucedidos (nas Minas Gerais) e com o comércio de escravos (nas áreas de Cuiabá e Goiás). Inclusive, sobre esta atividade, declarou em testamento ser detentor de 97 cativos, provavelmente destinados a transações mercantis.

Foi ministro da Ordem Terceira da Penitência de São Francisco ${ }^{26}$ e esteve à frente da Casa de Fundição de São Paulo, coordenando os trabalhos ao lado do tesoureiro Manuel Veloso 27 . Manuel Mendes de Almeida faleceu em 1754 com a alta patente de capitão-mor da cidade ${ }^{28}$. E, embora seu inventário tenha sido interrompido no meio do processo, um documento referente a contas de testamento que versa sobre a terça deixada de cerca de 15 contos de réis indica que seu patrimônio era bastante avultado ${ }^{29}$.

Natural de Vila Nova de Cerveira, comarca de Viana do Castelo, província do Minho, Manuel José da Cunha saiu de sua terra natal em 1716, para viver durante dois anos em Lisboa. De lá, embarcou na nau Santa Rosa em direção ao Rio de Janeiro e, antes de chegar a São Paulo, morou alguns anos em Cuiabá. Na freguesia de Cotia, casou-se com Maria de Lima de Camargo ${ }^{30}$, cujos pais - Maria de Lima de Camargo e Fernando de Camargo Ortiz - pertenciam a tradicionais famílias piratininganas ${ }^{31}$.

A aliança matrimonial estabelecida com membros da elite agrária certamente também deve ter concorrido para a projeção social alcançada pelo licenciado, uma vez que ele foi eleito para os mais altos cargos nas irmandades da cidade de São Paulo ${ }^{32}$, além de ter sido um dos poucos agentes mercantis a desempenhar o ofício de juiz ordinário na Câmara Municipal ${ }^{33}$.

Entre o casamento (1733) e o falecimento de Manuel José da Cunha (1746), transcorreram-se apenas 13 anos, mas foi o suficiente para que ele amealhasse uma fortuna considerável, avaliada em cerca de 15 contos de réis, assentada principalmente em dívidas ativas, dinheiro amoedado, e bens comerciais provenientes da loja de fazenda seca e da botica que possuía. $\bigcirc$ homem de negócio não dispunha de bens de raiz nos arredores de São Paulo, mas morava nos Quatro Cantos, numa residência bastante imponente para seu tempo /descrita mais à frente), além de ser proprietário de uma pequena morada situada na rua de Nossa Senhora do Rosário dos Pretos ${ }^{34}$.
24. Ver, no Arquivo do Estado de São Paulo, Sesmarias, patentes e provisões, livro 3 , f. $14 ;$ livro 5 , f. $7 \mathrm{v}$.

25. Ver o registro relativo a Manuel Mendes de Almeida no Arquivo do Estado de São Paulo, Juízo de Órfãos. Inventários e testamentos, C00532-1756.

26. Cf. Adalberto Ortmann (1951, p. 428 e 430).

27. Cf. Documentos Interessantes para a História e Costumes de S. Paulo, 61 São Paulo: Typographia Andrade \& Mello, 1902. p. 55-56.

28. Cf. Actas da Camara Municipal de S. Paulo, 11 São Paulo: Typographia Piratininga, 1916. p. 424-425.

29. Ver o registro relativo a Manuel Mendes de Almeida no Arquivo do Estado de São Paulo, Juízo dos Resíduos. Autos de contas de testamento, 05470 , doc.005.

30. Ver o registro relativo a Manuel José da Cunha, no Arquivo da Cúria Metropolitana de São Paulo, Dispensas e processos matrimoniais 4-4-18, 1733.

31. Cf. o volume 1 de Luiz Gonzaga da S. Leme (2002, p. 377).

32. Cf. Adalberto Ortmann (1951, p. 429); ver Livro das eleições e dos inventários da fábrica da Irmandade do Santíssimo Sacramento no Arquivo da Cúria Metropolitana de São Paulo.

33. Cf. Actas da Camara Municipal de S. Paulo, 12. São Paulo: Typographia Piratininga, 1918. p. 8-9.

34. Ver o registro relativo a Manuel José da Cunha no Arquivo do Estado de São Paulo, Juízo de Órfãos. Inventários e testamentos, C00651-1746. 
35. Ver nota 3

36. Cf. o volume 1 de Pedro Taques de A. P. Leme (1980, p. 174)

37. Ver o registro relativo a Gregório de Castro Esteves, no Arquivo da Cúria Metropolitana de São Paulo, Processos de divórcio e nulidade de casamento, 15-1-3, 1729.

38. Ver o registro relativo a Inácio da Costa de Siqueira, no Arquivo da Cúria Metropolitana de São Paulo, Dispensas e processos matrimoniais, 4-11-67, 1739.

39. Ver o registro relativo a Tomé Rabelo Pinto, no Arquivo da Cúria Metropolitana de São Paulo, Dispensas e processos matrimoniais, 4-4-18, 1733.

40. Ver o registro relativo a Lopo dos Santos Serra, no Arquivo da Cúria Metropolitana de São Paulo, Registros de casamento, Catedral da Sé, livro 2, 1690-1767, 1-3-16, f. 108 .

41. Ver o registro relativo a José Rodrigues Pereira, no Arquivo da Cúria Metropolitana de São Paulo, Dispensas e processos matrimoniais, 4-29-174, 1745.

42. Ver o registro relativo a Manuel Mendes de Almeida no Arquivo do Estado de São Paulo, Juízo de Órfãos. Inventários e testamentos, C00532-1756.
As trajetórias narradas guardam traços comuns. Os "cabeças" eram reinóis; chegaram à colônia no início do século XVIII; eram proprietários de lojas de fazenda seca e de moradas no centro da capital; participaram dos órgãos de poder local - Câmara Municipal, irmandades e companhia de ordenanças -e casaram-se com filhas de famílias da terra.

Para além dos traços individuais de seus percursos, acompanharam várias mudanças político-administrativas sofridas pela região paulista. Veloso e Almeida vivenciaram a criação da Capitania Real de São Paulo e Minas do Ouro (1709) e a elevação da vila de São Paulo à categoria de cidade (171 1). Por outro lado, ao longo da primeira metade do século XVIII, assistiram à gradual supressão dos territórios da capitania - Minas Gerais, Santa Catarina, continente de São Pedro, Mato Grosso e Goiás -, culminando com a perda da sua autonomia política (1748) e a subordinação ao Rio de Janeiro e ao governo militar da Praça de Santos.

Entretanto, ao contrário da historiografia tradicional, que considera este contexto marcado pela pobreza, decadência e isolamento que grassavam na cidade e capitania de São Paulo em virtude da ausência de produtos de exportação ${ }^{35}$, as trajetórias desses homens - assim como de tantos outros comerciantes - indicam que seus negócios prosperaram neste período, inclusive incrementados pelas descobertas auríferas nas áreas de Cuiabá (1718) e Goiás (1725), cujas populações eram por eles abastecidas com mantimentos, escravos e animais. Fato é que os três alcançaram destaque socioeconômico local e faleceram antes do governo de D. Luis Antonio de Souza Botelho Mourão, o Morgado de Mateus, cujo mandato cobriu o período de 1765-1775.

Dos seis filhos de Manuel Veloso, os dois homens - Manuel e Bento - foram encaminhados à carreira eclesiástica ${ }^{36}$ e as quatro mulheres uniram-se a comerciantes reinóis, promovendo a transmissão da atividade mercantil de sogro para genro. Catarina desposou Gregório de Castro Esteves ${ }^{37}$, Maria Josefa contraiu núpcias com Inácio da Costa de Siqueira ${ }^{38}$, Angela Vieira casou-se com Luis Rodrigues Vilares, e Escolástica Vieira, viúva de Bento Gomes de Oliveira, uniu-se em matrimônio com Tomé Rabelo Pinto ${ }^{39}$. Não só estas duas últimas se vincularam a homens ligados ao comércio, como também tiveram genros comerciantes: Lopo dos Santos Serra ${ }^{40}$ e José Rodrigues Pereira ${ }^{41}$, respectivamente.

Semelhantes arranjos matrimoniais ocorreram na família de Manuel Mendes de Almeida. Dos oito filhos que teve, Manuel, Francisco e José tornaram-se monges beneditinos, Felipa faleceu solteira, Josefa Caetana Leonor casou-se com Gregório Dias da Silva, ouvidor da cidade de São Paulo na década de 1730, mas as três outras mulheres contraíram núpcias com comerciantes portugueses Maria Josefa casou-se com Francisco Pereira Mendes, Cecília contraiu matrimônio com Ventura Rodrigues Velho, e Catarina desposou Antonio Ferreira Lustosa -, que partilharam empreendimentos com o sogro ${ }^{42}$ 
Manuel José da Cunha, por sua vez, teve quatro filhos, sobre os quais se sabe que Fernando, o primogênito, tornou-se monge beneditino e, das filhas, pelo menos uma - Ana Eufrosina - desposou um mercador português, Manuel Rodrigues Jordão, sobrinho de Pereira Mendes ${ }^{43}$.

Esta nova geração, ainda reinol, de comerciantes conseguiu maior projeção socioeconômica do que a anterior, como atestam suas trajetórias de vida.

José Rodrigues Pereira saíra ainda adolescente da vila de Ruivais, na região do Minho, para a cidade do Porto, de onde deixou o reino. Na colônia, residira na cidade fluminense, em Goiás e até mesmo em São Paulo, e já se encontrava na América havia cerca de 25 anos quando, em 1745, desposou a enteada de seu primo Tomé Rabelo Pinto, Ana de Oliveira Montes, fruto do enlace de Escolástica Veloso com o primeiro marido, Bento Gomes de Oliveira ${ }^{44}$.

A partir do estreitamento de laços parentais numa família de comerciantes, Pereira passou a circular pelos órgãos de poder e prestígio social, ocupando os mais elevados cargos. Foi juiz ordinário na Câmara Municipal45, provedor da irmandade do Santíssimo Sacramento da Sé ${ }^{46}$ e ministro da Ordem Terceira da Penitência de São Francisco ${ }^{47}$, e, ainda, cavaleiro da Ordem de Cristo ${ }^{48}$.

Em testamento, declarou ser homem de negócio, na cidade e fora dela, com correspondentes em várias localidades, e possuidor de duas lojas de fazenda seca na capital e uma em Mogi das Cruzes. No inventário, aberto em 1770, a soma dos bens atingiu cerca de 26 contos de réis ${ }^{49}$. Ainda que as dívidas passivas tivessem diminuído seu patrimônio, as ativas representaram a maior receita na composição do patrimônio do sargento-mor, com devedores residentes em solo piratiningano, nas minas de Cuiabá e Goiás, na cidade do Rio de Janeiro e nas vilas de Paranaguá, Santos, Jundiaí e Araçariguama, o que revela a amplitude das transações mercantis realizadas.

Detentor de 14 escravos, Pereira também residia nos Quatro Cantos, numa morada de casas de sobrado, grandes, cobertas de telhas e com paredes de taipa de pilão. Era proprietário de bens de raiz na roça, destinados à criação de mais de uma centena de reses, talvez herdados por sua esposa, pois os imóveis se localizavam nas mesmas paragens descritas no inventário do avô Manuel Veloso.

Ao falecer, em 1769, deixou 8 filhos. Das mulheres, duas contraíram matrimônio com dois irmãos ligados às atividades comerciais, filhos do homem de negócio Francisco de Sales Ribeiro: Maria Joaquina casou-se com Manuel Francisco de Sales e Ana Joaquina desposou José Francisco de Sales. Nenhum dos filhos homens, porém, envolveu-se exclusivamente com a lide mercantil - José foi encaminhado à carreira eclesiástica, Joaquim, ao serviço militar e Antonio Rodrigues Veloso de Oliveira foi para Coimbra, onde se formou em leis em 1779; atuou como desembargador do Paço e, em 1822, participou como deputado na Assembléia Constituinte do Império do Brasil50.
43. Ver o registro relativo a Manuel Rodrigues Jordão, no Arquivo da Cúria Metropolitana de São Paulo, - Dispensas e processos matrimoniais - 5-13-801 - 1767.

44. Ver o registro relativo a Manuel Rodrigues Jordão, no Arquivo da Cúria Metropolitana de São Paulo, - Dispensas e processos matrimoniais - 4-29-174 - 1745.

45. Cf. Actas da Camara Municipal de S Paulo, 13. São Paulo: Typographia Piratininga, 1918. p. 525-526.

46. Ver o Livro das eleições e dos inventários da fábrica da Irmandade do Santíssimo Sacramento, no Arquivo da Cúria Metropolitana de São Paulo.

47. Cf. Adalberto Ortmann (1951, p. 431).

48. Ver o registro relativo a José Rodrigues Pereira, no Instituto dos Arquivos Nacionais da Torre do Tombo (IANTT), Habilitações da Ordem de Cristo, letra J, maço 24, n. 2, 1763.

49. Ver o registro relativo a José Rodrigues Pereira no Arquivo do Estado de São Paulo, Juízo de Órfãos. Inventários e testamentos, C00612-1770.

50. Cf. o volume 8 de Luiz Gonzaga da S. Leme (2002, p. 383-87). Sobre o encaminhamento dado aos herdeiros varões pelas famílias na cidade de São Paulo setecentista, ver Muriel Nazzari (2001). 
51. Ver o registro relativo a Francisco Pereira Mendes, no Arquivo da Cúria Metropolitana de São Paulo, Dispensas e processos matrimoniais, 4-44-270, 1749.

52. Documentos Interessantes para a História e Costumes de S. Paulo, 62. São Paulo: Instituto Historico e Geographico de S. Paulo, 1937. p. 60.

53. Ver o registro relativo a Francisco Pereira Mendes no Arquivo do Estado de São Paulo, Juízo de Órfãos. Inventários e testamentos. C00664-1782.

54. Ver o registro relativo a Francisco Pereira Mendes no IANTT - Habilitações da Ordem de Cristo - letra F maço 4 - n. 4 - 1749 .

55. Cf. Actas da Camara Municipal de S. Paulo, 13. São Paulo: Typographia Piratininga, 1918, p. 564-5.

56. Ver o Livro das eleições e dos inventários da fábrica da Irmandade do Santíssimo Sacramento, no Arquivo da Cúria Metropolitana de São Paulo.

57. Cf. Adalberto Ortmann (1951, p.432)

58. Ver o registro relativo a Francisco Pereira Mendes no Arquivo do Estado de São Paulo, Juízo de Órfãos. Inventários e testamentos, C00664-1782.

59. Ver o registro relativo a Joaquim José dos Santos, no Arquivo da Cúria Metropolitana de São Paulo, Dispensas e processos matrimoniais, 6-23-1881, 1789.

60. Ver o registro relativo a Manuel Antonio de Araújo, no Arquivo da Cúria Metropolitana de São Paulo, Dispensas e processos matrimoniais, 5-52-1261, 1777.

61. Cf. o volume 1 de Luiz Gonzaga da S. Leme (2002, p.463)
Francisco Pereira Mendes também era natural da província do Minho, comarca de Barcelos, onde foi batizado em 1710. Antes de chegar à capital paulista, entretanto, residira nas minas de Goiás, onde fora capitão das tropas auxiliares de cavalos, sem ocupação declarada ${ }^{51}$. Entretanto, já em solo piratiningano, foi registrado, no censo de 176752, como vivendo de seus negócios e, em inventário datado de 1782, foram avaliadas as mercadorias da loja de fazenda seca que possuía ${ }^{53}$.

Portanto, no seu caso, talvez o casamento com Maria Josefa Mendes da Silva, filha de um comerciante, tenha lhe aberto as portas para o mundo dos negócios e facilitado a projeção social, por meio da participação nos órgãos de poder local e da alcançada mercê de cavaleiro da Ordem de Cristo ${ }^{54}$. Pereira Mendes desempenhou o ofício de vereador na Câmara Municipal ${ }^{55}$, de provedor na lrmandade do Santíssimo Sacramento da Sé ${ }^{56}$ e de ministro da Ordem Terceira da Penitência de São Francisco 57.

O sucesso da carreira mercantil, conjugado ao dote e à herança trazidos para o casal por sua esposa, pode ser comprovado pelo cabedal acumulado que, na abertura do inventário, ultrapassava a cifra de 40 contos de réis.

Francisco Pereira Mendes residia em um sítio nas bandas dos Pinheiros - "com casas de vivenda, de três lanços térreas, grandes com varandas, com seu oratório ou capelinha dentro [...], várias imagens, tudo com muito asseio, quintal murado grande com vários arvoredos de espinhos, jabuticabeiras, água por cima, roda de mandioca de água, prensa, casa de fornalhas, duas casinhas fora, várias senzalas" 58 -, no qual trabalhavam 23 escravos e onde cultivava alimentos e criava gado. Entretanto, a morada de casas (em que a esposa vivia na época do inventário) estava localizada nos Quatro Cantos, e fora herdada de seu sogro, assim como a sesmaria de uma légua, em quadra no bairro de Caucaia, freguesia de Cotia.

Ao falecer, o abastado comerciante deixou seis herdeiros. Uma de suas filhas - Antonia Joaquina - casou-se com Joaquim José dos Santos ${ }^{59}$; e Gertrudes Maria, a irmã, foi a segunda esposa do negociante Manuel Antonio de Araújo60. Bartolomeu, o varão mais velho, seguiu a carreira eclesiástica, mas o seguinte, homônimo do pai, contraiu núpcias com Maria Hipólita, filha do alferes Manuel Rodrigues Jordão61.

Proveniente de Figueiró dos Vinhos, mesma freguesia da qual era oriundo Manuel Mendes de Almeida, Jordão nascera por volta de 1727. Bem jovem, imigrou para a América Portuguesa, onde diversos parentes já se encontravam estabelecidos. Primeiro, circulou com mercadorias pelas regiões de Goiás e Cuiabá, chegando a São Paulo com cerca de 40 anos, com algum o ouro adquirido nas minas. Logo depois, contraiu núpcias com a vizinha Ana Eufrosina, filha do já defunto Manuel José da Cunha ${ }^{62}$.

Quando morreu em 1785, Jordão residia na rua de São Bento, numa morada térrea, e dispunha de outro sobrado, nos Quatro Cantos, que the coube em partilhas pelo falecimento de sua sogra e que se achava em litígio com Dr. Luiz de Campos, segundo marido dela. Era também proprietário de duas chácaras 
localizadas no caminho de Penha e possuidor de 23 escravos. Seu patrimônio foi avaliado em cerca de 15 mil réis ${ }^{63}$.

A proeminência socioeconômica destes agentes mercantis não foi atestada apenas a partir dos dados coletados nos inventários, pois seus contemporâneos já os reconheciam como figuras de destaque na sociedade paulistana da segunda metade do século XVIII, tanto que José Rodrigues Pereira e Francisco Pereira Mendes foram considerados os mais ricos habitantes da cidade de São Paulo pelo censo de $1765^{64}$. Além das fortunas amealhadas no comércio, ambos ocuparam os mais altos postos das instituições locais de prestígio social, foram agraciados com a mercê de cavaleiros da Ordem de Cristo, e o primeiro, tal como outros homens de negócio de seu tempo, encaminhou um filho para a Universidade de Coimbra, indicando a estratégia de promover socialmente os descendentes varões por meio dos estudos na metrópole e a possível atuação na vida pública quando retornados ${ }^{65}$.

É bem possível que o ingresso em famílias de comerciantes (de origem portuguesa, como eles próprios) já estabelecidos e conhecidos na praça, associado aos negócios realizados previamente nas áreas mineradoras de Cuiabá e Goiás, tenha lhes facilitado o sucesso na carreira mercantil e na ocupação de postos nos órgãos de poder. Com casas de morada nos Quatro Cantos, eram possuidores de lojas de fazenda seca; faziam viagens ao Rio de Janeiro ou encomendavam de lá mercadorias para seus estabelecimentos, e abasteciam as regiões auríferas.

Trilhando carreiras tipicamente mercantis até o final de suas existências, os três faleceram entre as décadas de 1760 e 1780, quando na capitania estavam se esboçando as atividades agrícolas de exportação e os resultados promissores ainda eram poucos. Ainda que não tivessem se dedicado mais incisivamente ao cultivo de cana, os negócios realizados pelos grandes homens de comércio, membros de uma elite mercantil que crescia e ganhava importância na capital durante a segunda metade do século XVIII, certamente prepararam o terreno para a bem sucedida montagem da lavoura empresarial.

Seus descendentes, entretanto, nascidos em solo colonial no século XVIII e falecidos entre as décadas de 1820 e 1830, por sua vez, vivenciaram uma nova conjuntura econômica favorável aos negócios de açúcar, seja relacionada à produção de cana, à mão-de-obra escrava e/ou ao transporte do produto, com os quais se envolveram de forma bem sucedida, diversificando suas atividades econômicas, com a conjugação de atividades mercantis e agrárias ${ }^{66}$.

Na verdade, a multiplicidade de interesses a que estavam ligados denota o papel decisivo destes comerciantes para o movimento de importação e exportação de mercadorias, articulando a cidade de São Paulo com as áreas interioranas, com o Rio de Janeiro, e com Lisboa. Nesse sentido, o caso de Joaquim José dos Santos, filho de Lopo dos Santos Serra e descendente de Manuel Veloso, é emblemático, como se vê pelo seu registro no maço de população de 1798: "vive do negócio de escravos que manda vir do Rio de Janeiro à vila de Santos
62. Ver o registro relativo a Manuel Rodrigues Jordão, no Arquivo da Cúria Metropolitana de São Paulo - Dispensas e processos matrimoniais - 5-13-801 - 1767.

63. Ver o registro relativo a Manuel Rodrigues Jordão no Arquivo do Estado de São Paulo, Inventários e testamentos, C00652-1786.

64. Cf. Documentos Interessantes para a História e Costumes de S. Paulo, 42,. São Paulo: Instituto Historico e Geographico de S. Paulo, 1937. p. 59-60.

65. Para que se tenha idéia da relevância numérica dos estudantes cujas famílias estavam atreladas às atividades comerciais, basta dizer que eles representavam $64 \%$ do conjunto de paulistanos que estiveram na Universidade de Coimbra entre os anos de 1772 e 1827 (data da fundação da Faculdade de Direito do Largo São Francisco). Cf. Anais da Biblioteca Nacional do Rio de Janeiro, v. 62, p. 141-305, 1940.

66. Sobre as transformações ocorridas na sociedade colonial na segunda metade do século XVIII até o primeiro quartel do século XIX, com destaque para as formações sociais do centro-sul da América Portuguesa, ver Cecília H. de S. Oliveira (1995, p. 7-31). 
67. Arquivo do Estado de São Paulo, Maços de população, 1798. Disponível em <www. arquivoestado.sp.gov.br/ver/ res_frameset.php?ident $=032$ _020\&img=032_020_001. jpg>. Acesso em 13 mai. 2010.

68. Sobre as fortunas e os padrões de investimentos do setor mercantil na cidade de São Paulo durante a primeira metade do século XIX, ver Maria Lucília V. Araújo (2006).

69. Corrobora essa possibilidade o fato de que em 1809 o registro da primeira décima acusa que este lote estava em construção. Cf. prancha publicada por Beatriz P. S. Bueno (2005, p. 67)

70. Ver o registro relativo a Manuel Rodrigues Jordão (brigadeiro), no Arquivo do Tribunal de Justiça do Estado de São Paulo, Inventários do $1^{\circ}$ cartório de família, proc. 229. 1828 .

71. Cf. o volume 1 de Luiz Gonzaga da S. Leme (1903, p. 215). para os vender na vila de ltu e de açúcar que na tal vila compra para remeter à Lisboa"67.

Todos os agentes mercantis mencionados até o momento eram senhores de escravos, mas, na documentação censitária, ainda não havia informações específicas sobre o envolvimento com o trato dos viventes, ainda que o número de peças registrado nos inventários indicasse que o comércio de cativos se inseria nos negócios realizados por aqueles mercadores e homens de negócios.

Pelos dados extraídos dos maços de população no tocante à diversificação das atividades econômicas desempenhadas pelos agentes mercantis, é legítimo afirmar que o estímulo agrícola governamental, iniciado pelo Morgado de Mateus - fruto da política pombalina - e continuado por seus sucessores, além de não ter ofuscado, na sociedade paulistana, o papel do comerciante - que já alcançara relevo em meados do século XVIII -, incrementou os negócios deste segmento social cada vez mais proeminente, não só no cenário da cidade, mas agora, também, da capitania/província de São Paulo em fins do período colonia|b8.

Entre as maiores fortunas da primeira metade do século XIX - a léguas de distância dos patrimônios considerados avultados no século XVIII paulista-, destacam-se a do brigadeiro Manuel Rodrigues Jordão (descendente de Manuel José da Cunha), a do cunhado marechal-de-campo Joaquim Mariano Galvão de Moura Lacerda, e a do seu parente, o coronel Joaquim José dos Santos (descendentes de Manuel Veloso).

O brigadeiro Jordão era proprietário de imóveis na rua Direita, na rua Santo Antonio e, ainda, da chácara das Paineiras, no lpiranga. A morada em que residia nos Quatro Cantos era de três lanços, cinco portas, cinco janelas, com grades de ferro e quintal, onde trabalhavam 24 escravos. De acordo com a localização indicada no inventário, esta morada se situava no mesmo terreno em que outrora residira seu avô Manuel José da Cunha, o que não significa tratar-se do mesmo imóvel, amplamente reformado ao longo do tempo ou mesmo reconstruído, dadas as características descritas ${ }^{69}$.

Além dos citados 24 escravos urbanos, o brigadeiro Jordão possuía cerca de 300 cativos espalhados pelo interior da capitania: nos engenhos de Benfica, Queluz e Rosário, em Itu; no engenho do Paraíso, em Piracicaba; na sesmaria, em Salto Grande do Curubataí; na fazenda Dois Corações, em Itapetininga; na fazenda Espírito Santo, em Jacareí; na fazenda do Bonfim, em Taubaté; na fazenda do Natal, em Pindamonhangaba; e na fazenda de Santo Antonio das Palmeiras, em Areias ${ }^{70}$. As atividades agrárias eram mescladas às de comerciante, que giravam em torno de fazenda seca, tropas de mulas e mercadorias de botica. Na esfera política, segundo Silva Leme, foi "cidadão notável por sua riqueza e prestígio; membro do governo provisório em 1821 em São Paulo; tesoureiro da Junta da Fazenda e conselheiro do governo"71.

Ao falecer, em 1827, deixou cinco filhos do matrimônio com Gertrudes Galvão de Oliveira Lacerda - Ana Eufrosina, Manuel Rodrigues Jordão, Amador de Camargo Lima, Silvério Rodrigues Jordão, Gertrudes - e um natural, Antonio Rodrigues de Almeida Jordão, enviado no ano anterior à Universidade de Coimbra 
para realizar os estudos de Filosofia ${ }^{72}$. No inventário, aberto em 1828, o monte partível foi avaliado em cerca de 311 contos de réis, quantia que o colocou entre os paulistanos mais ricos de seu tempo. Além disso, a fortuna avultada do brigadeiro revela o enriquecimento fenomenal de membros daquelas famílias constituídas, cerca de cem anos antes, em torno da atividade mercantil.

Seu cunhado Joaquim Mariano Galvão de Moura Lacerda, negociante e fazendeiro, residia na capital, num sobrado da rua Boa Vista. Nos arredores possuía as chácaras Alecrim, Rosa e Boa Vista, localizadas na freguesia do Brás. Na cidade de São Paulo, era detentor de 33 escravos, entretanto, em inventário aberto em 1834, havia arroladas duas centenas de cativos, que estavam distribuídas em sítios e fazendas, sugerindo que o marechal de campo também estava envolvido com o comércio de escravos. No distrito de Santa Bárbara, da vila de Constituição, era proprietário do engenho São Joaquim, no qual produzia açúcar e café e tinha um pouso para tropas; e, na vila de São Bento de Araraquara, a fazenda de criar denominada Santa Joana.

De seu matrimônio com Joana Emília Veloso de Oliveira, filha de seu tio materno Antonio Rodrigues Veloso de Oliveira e de Tereza Emília, teve quatro filhos - Joaquim Mariano Galvão de Moura Lacerda, Júlio Galvão de Moura Lacerda, Paulo Mariano Galvão de Moura Lacerda, D. Luiza Emília Galvão de Moura Lacerda - aos quais legou um patrimônio líquido de cerca de 124 contos de réis, composto majoritariamente por escravos, imóveis e dívidas ativas ${ }^{73}$.

Também era do negócio de cativos e de açúcar que o coronel Joaquim José dos Santos auferia lucros, como se constatou pelo registro de sua ocupação no maço de população 1798; e, em inventário aberto em 1828, foram arrolados 87 escravos $^{74}$. Além disso, é provável que vivesse das rendas dos dez imóveis de que era proprietário no centro da capital, além das da produção agrícola da chácara do Campo Redondo e da fábrica de açúcar localizada em Jundiaí. Pelos dados da Décima Urbana de 1809, parece que já desempenhava a atividade de rentista há muitos anos, pois os cinco bens de raiz que possuía naquela época já o colocavam entre os vinte proprietários detentores de maior patrimônio imobiliário na cidade de São Paulo ${ }^{75}$.

Em 1789, no oratório da propriedade de seu tio paterno, o mestre de campo Francisco Xavier dos Santos, contraiu núpcias com Antonia Joaquina Mendes da Silva, filha de Francisco Pereira Mendes e Maria Josefa Mendes da Silva ${ }^{76}$. Residente na rua Direita, no canto do Chafariz, número 10, casa de sobrado, com seis janelas na frente de paredes de pilão, cobertas de telhas, toda forrada e assoalhada, com seu quintal. $\bigcirc$ casal teve oito filhos - Francisco Xavier dos Santos, Joaquim José dos Santos Silva, José Francisco Xavier dos Santos, Antonio Rodrigues Vilares, Francisca Vitória Rodrigues, Maria Violante do Céu, Inácia Joaquina dos Santos e Manuel Rodrigues Vilares, enviado a Portugal em 1818 para a realização dos cursos de Matemática e Direito na Universidade de Coimbra ${ }^{77}$, e posteriormente ouvidor na Bahia.
72. Cf. Anais da Biblioteca Nacional do Rio de Janeiro, v. 62 , p. $265,1940$.

73. Ver o registro relativo a Joaquim Mariano Galvão de Moura Lacerda, no Arquivo do Tribunal de Justiça do Estado de São Paulo, Inventários do $1^{\circ}$ cartório de família, proc. 721. 1834.

74 Ver o registro relativo a Joaquim José dos Santos, no Arquivo do Tribunal de Justiça do Estado de São Paulo, Inventários do $1^{\circ}$ cartório de família, proc. 427.1828 .

75. Arquivo do Estado de São Paulo, Livro da Décima de 1809, apud Beatriz P. S. Bueno (2005, p. 79)

76. Ver o registro relativo a Joaquim José dos Santos, no Arquivo da Cúria Metropolitana de São Paulo, Dispensas e processos matrimoniais, 6-23-1881, 1789

77. Cf. Anais da Biblioteca Nacional do Rio de Janeiro, v. 62 , p. $237,1940$. 
78. Sobre a importância das ruas Direita e São Bento para o desenvolvimento das atividades comerciais na passagem do século XIX para o $\mathrm{XX}$, ver Heloisa Barbuy (2006).

79. Cf. Carlos A. C. Lemos (2004, p. 165)

80. Cf. Documentos Interessantes para a História e Costumes de S. Paulo, 73. São Paulo: Instituto Historico e Geoghaphico de S. Paulo, 1952. p. 62.

81. Cf. Benedito Lima de Toledo (2007, p. 12).

82. Cf. Documentos Interes santes para a História e Costumes de S. Paulo, 62. São Paulo: Instituto Historico e Geoghaphico de S. Paulo, 1937 , p. 9

83. Idem, p. 1-256
A narração dos retalhos de vida dos personagens dessa última geração não só pretendeu mostrar como suas atividades estavam assentadas nas práticas mercantis e agrárias, mas, antes, que não dependeram exclusivamente da atuação de homens do século XIX, iá que seus antepassados, ou os de suas esposas reinóis e comerciantes -, haviam lhes legado negócios e fortunas, cuja materialidade em parte se expressou por bens imóveis e móveis.

Espaço urbano, comércio e vida material

Todos os sujeitos mencionados viveram na cidade de São Paulo, na área mais central do espaço urbano, caracterizada pelo Triângulo, concentrando aí suas residências e lojas de fazenda seca. Como já se comentou, tal conduta não foi exclusiva dos membros dessas famílias, mas, antes, representou o comportamento adotado pela elite mercantil naquele contexto, o que nos autoriza a antecipar a configuração de tal área como centro comercial, ainda que incipiente, para meados do século XVIII78. $\bigcirc$ Quatro Cantos, tão disputado na primeira metade do século XIX pela elite paulistana, fora o local de residência de abastados comerciantes no século anterior.

À época da chegada do Morgado de Mateus, o centro da capital era formado por cerca de dez ruas bem definidas, articuladas por becos e travessas, pelos mais destacados templos e seus largos, e pelos pátios do Colégio e da Sé79. Em correspondência datada de 10 de dezembro de 1766, endereçada ao conde de Oeiras, o governador comentou que "está edificada a cidade de São Paulo, no meio de uma grande campina em sítio num elevado, que a descobre toda em roda. $O$ seu terreno é brando e tem as ruas planas, largas e direitas e algumas bem compridas, porém, não são calçadas, todas as paredes dos edifícios são de terra $[\ldots]^{\prime \prime 80}$. Embora a descrição ainda tenha continuação, o destaque para o caráter de "acrópole", atribuído à urbe com ruas planas presente neste curto fragmento, revela que a sua concepção da cidade - certamente expoente da noção corrente em meados do século XVIII - restringia-se ao "platô" do Triângulo ${ }^{81}$.

De acordo com os dados do primeiro censo realizado após a restauração da capitania, a população livre residente na freguesia da Cidade, que compreendia as companhias da Cidade, de Nossa Senhora do Ó e Santana, de Caguaçu e São Miguel 82 , correspondia a 1748 homens e 2090 mulheres, distribuídos em 899 domicílios, dos quais 66 eram chefiados por comerciantes ${ }^{83}$. Se a representatividade numérica do grupo mercantil parece pequena, o mesmo não pode ser dito de seus cabedais, que correspondiam a cerca de $45 \%$ de toda a riqueza declarada e garantiam ao grupo o destaque econômico na sociedade paulistana.

Manuel Cardoso de Abreu, que percorreu várias localidades da capitania durante seu itinerário a Cuiabá entre os anos de 1765 e 1773, captou 
o papel crucial dos comerciantes para o desenvolvimento da cidade neste período. Sobre os habitantes da capital, informou que

vivem de várias negociações: uns se limitam a negócio mercantil, indo à cidade do Rio de Janeiro buscar as fazendas para nela venderem; outros da extravagância dos seus ofícios; outros vão a Viamão buscar tropas de animais cavalares ou vacuns para venderem, não só aos moradores da mesma cidade e seu continente como também aos andantes de Minas Gerais, e exercitam o mesmo negócio vindo comprar os animais em São Paulo para os ir vender a Minas, e outros, finalmente, compram alguns efeitos da mesma capitania, como são panos de algodão e açúcar, e vão vender às Minas, labutando nesta forma todos naquilo a que se aplicam ${ }^{84}$.

Decorrido quase meio século, segundo dados da décima urbana de 180985, a estreita colina - área efetivamente urbanizada -, delimitada pelos rios Tamanduateí e Anhangabaú, com pouquíssimas ramificações na várzea, compunha-se de um total de 34 ruas, um beco e quatro largos. De acordo com tal documentação, dez dos treze imóveis mais caros, inventariados para fins de tributação, tinham uso comercial ou misto, e os comerciantes se encontravam entre os proprietários detentores dos maiores patrimônios imobiliários da cidade ${ }^{86}$.

No intervalo temporal compreendido entre os anos de 1765 e 1809, é possível, portanto, observar o crescimento espacial do centro da cidade e a contribuição significativa do grupo mercantil para produção de boa parte do tecido urbano de São Paulo. Para as décadas seguintes, a área central ainda seria marcada pelo adensamento populacional e pela diversificação profissional de seus habitantes ${ }^{87}$.

Essa faceta da vida urbana paulistana chamou a atenção de Auguste Saint-Hilaire. Ao fazer anotações sobre a cidade visitada na década de 1820, registrou que "funcionários de todas as ordens, operários de diversas categorias, um grande número de mercadores, proprietários de casas urbanas, proprietários de bens rurais que, ao contrário dos de Minas Gerais não moram em suas fazendas, compõem a população da cidade de São Paulo, onde se contam também várias pessoas que vivem da venda de legumes e frutas cultivadas em suas próprias chácaras" 88

As impressões do viajante correspondem justamente à situação dos homens de negócio selecionados no diagrama, falecidos nas décadas de 1820-1830. Embora residissem no centro da cidade de São Paulo e tivessem chácaras nos arredores (como seus antepassados), seus negócios se estendiam pelo interior da capitania (e posteriormente província), inclusive com o estabelecimento de propriedades agrárias, algo incomum nas gerações anteriores, que se limitavam a abastecer com mercadorias as vilas próximas e distantes, e a promover relações de endividamento com seus moradores. A variação da localização dos imóveis ao longo do tempo pode ser compreendida, portanto, à luz do fortalecimento da endogamia mercantil e de seu papel decisivo para as mudanças socioeconômicas vivenciadas pela capitania/província de São Paulo desde meados do XVIII.

As duas primeiras gerações abordadas, compostas de reinóis em fase de sedimentação, realizaram um movimento de confluência para a cidade de São
84. Cf. Manuel Cardoso de Abreu (1977, p. 83-84).

85. Pelo documento, os proprietários de todos os prédios urbanos habitados passavam a pagar anualmente para a Fazenda Real $10 \%$ do rendimento líquido dos imóveis. Ver Alvará-RJ, 03.06.1809, [s/n], v. 792, na Coleção Alberto Penteado de leis, decretos e alvarás.

86. Cf. Beatriz P. S. Bueno (2005, p. 66, 76 e 79).

87. Cf. Maria Lucília V. Araújo (2006, p. 41-53).

88. Cf. Auguste de Saint-Hilaire (1976, p. 127). 
89. Idem., p. 128.

90. Cf. Carlos A. C. Lemos (1999, p. 25).

91. Ver o registro relativo a Manuel Rodrigues Jordão (brigadeiro), no Arquivo do Tribunal de Justiça do Estado de São Paulo, Inventários do $1^{\circ}$ cartório de família, proc. 229. 1828

92. Ver o registro relativo a Joaquim José dos Santos, no Arquivo do Tribunal de Justiça do Estado de São Paulo, Inventários do $1^{\circ}$ cartório de família, proc. 427.1828 .
Paulo, onde definitivamente se radicaram, com moradias e lojas de fazenda seca. Já a terceira geração, nascida em solo paulistano, em famílias consolidadas, promoveu um movimento em sentido contrário, de irradiação dos negócios, agora fincando raízes em outras localidades da província, por meio da propriedade de residências urbanas, fazendas, sítios e engenhos.

A esmagadora maioria dos imóveis avaliados nos inventários das três gerações, localizados no centro da capital paulista, era de taipa de pilão - sistema construtivo tradicional -, cuja predominância em solo piratiningano é também confirmada pelas considerações tecidas pelo Morgado de Mateus sobre a "cidade de barro", em 1766, e as impressões de Saint-Hilaire, meio século depois, acerca das casas: "feitas de taipa e bastante sólidas, são todas caiadas e cobertas de telhas" 89 .

Entretanto, se houve permanência da técnica construtiva, o mesmo não pode ser dito em relação a outros itens levados em consideração no momento da avaliação dos imóveis. Até fins do século XVIII, a descrição, em geral, limitava-se a dar conta da localização, do número de pavimentos e de lanços, e dos confrontantes. Já na primeira metade do século XIX, além dessas, surgiram novas informações: as casas passaram a ser numeradas, em razão da Décima Urbana; as portas e janelas, contadas; novos materiais e elementos arquitetônicos, introduzidos; e eram mencionadas repartições internas.

E "sobrado", ao longo dos anos, foi assumindo diferentes significados, denotativos das transformações ocorridas tanto nas formas de morar como no espaço urbano. Para compreendê-lo, é fundamental considerar que "sobrado", muitas vezes, não necessariamente indicava dois andares, mas antes correspondia ao espaço que sobrou, tanto acima do teto - sótão - como abaixo do soalho porão ${ }^{90}$. Para o universo mercantil, este esclarecimento sugere que, caso a construção tivesse um único pavimento, a loja de fazenda seca se localizava no mesmo nível da residência do comerciante, ao passo que a existência de dois pavimentos demarcava a cisão entre o mundo do trabalho e o familiar, com o estabelecimento comercial alocado no térreo e os aposentos domésticos no primeiro andar.

As variações na acepção do vocábulo indicam que, no século XVIII, o comum era a existência de casas térreas e de "falsos" sobrados - denominados na documentação como casas assobradadas, sobradinhos, sobradinhos muito baixos ou mesmo sobrados -, cujos sótãos teriam aberturas situadas sob os beirais, destinados à estocagem de grãos ou ao dormitório dos escravos.

Exemplares desta natureza aparecem nos espólios do brigadeiro Jordão e de Joaquim José dos Santos, ambos abertos em 1828. O primeiro era possuidor de "uma morada de casas com um sobradinho muito baixo, sitos na rua Direita desta cidade, de dois lanços, parede de pilão, cobertas de telhas com um pequeno quintal, muito velhas"91. Já no processo do segundo, o imóvel é assim descrito "outra morada de casas também sitas nesta cidade, na mesma rua do Ouvidor, número 49, com um sobradinho com três portas"92.

Há casos, entretanto, em que o imóvel não chega a ter caracterização definida, como é o caso da residência de Manuel José da Cunha, falecido em 
1746, assim mencionada pelos avaliadores: "uma morada de casas sitas nos quatro cantos com sete lanços a saber três lanços térreos para a parte da rua Direita e quatro lanços para a parte da rua de São Bento de sobrado [...] com algumas madeiras, tijolos e telhas"93.

Por outro lado, também há informações precisas, que não deixam margem para dúvida quanto ao número de pavimentos existentes. No inventário de Francisco Pereira Mendes, aberto em 1782, o imóvel é assim descrito: "uma morada de casas na rua Direita, ou duas moradas místicas 94 , novas de sobrado, com lojas por baixo em que mora o mercador Ferraz e João Francisco de Vasconcelos"95. Ou no processo do brigadeiro Jordão, na parte referente ao recheio da casa" 96 , em que se avaliam em determinado momento "Mais madeiras existentes embaixo no escritório e quarto de hóspedes"97. Ou ainda na descrição de um imóvel de Joaquim Mariano Galvão de Moura Lacerda, falecido em 1834, em que o sobrado é percebido pelos componentes da fachada: "uma morada de casas, sitas na rua da Boa Vista desta cidade de número 53, com cinco janelas de frente, de dois lanços, com grades de ferro, tanto em cima quanto embaixo, toda forrada e assoalhada, com grande fundo, toda envidraçada e forrada com papel pintado, com grande quintal que vai até o rio chamado Tamanduateí" ${ }^{\prime \prime}$.

As inovações nas descrições dos bens de raiz do século XIX, ressaltando tanto a divisão e decoração internas (com a individuação dos cômodos) como a aparência externa (com a introdução de novos elementos construtivos), denotam outras mudanças em curso na forma de morar em São Paulo e de conceber o espaço doméstico.

Ao estudar a introdução e o desenvolvimento de novos conceitos de higiene e conforto na arquitetura paulistana da época imperial, Eudes Campos chama a atenção para a "remoção das treliças, ditas adufas ou rótulas, que até o início do século XIX guarneciam sistematicamente as aberturas dos prédios residenciais e monásticos"99. A retirada das treliças e sua substituição por vidraças viriam acarretar transformações indeléveis não só para as casas, que passaram a ter fachadas visíveis, como também para as ruas, mais iluminadas pelo reflexo da luz que incidia sobre portas e janelas ${ }^{100}$

Ainda que as novas soluções tenham demorado a se efetivar na cidade de São Paulo graças à reação dos habitantes frente às práticas coercitivas ${ }^{101}$, já não existiam rótulas em vários imóveis da elite paulistana construídos ou reformados na década de 1820. Tal era o caso da morada de casas de Joaquim Mariano Galvão de Moura Lacerda.

As vidraças introduzidas na fachada da residência do marechal de campo sugerem, outrossim, uma maior intensidade da comunicação entre os ambientes interno e externo, inclusive deixando mais à mostra o mobiliário, antes restrito aos olhos dos membros da unidade familiar. Aos poucos, a casa abria-se para o convívio, à medida que o interior doméstico retirava do espaço público a exclusividade do desenvolvimento de relações sociais.

Nos finais do século XVIII e primeira metade do XIX, a habitação começa a ser dividida em recintos onde se podia conversar, jogar, tomar bebidas e receber visitas $^{102}$. No inventário do brigadeiro Jordão - em que parte do mobiliário foi
93. Ver o registro relativo a Manuel José da Cunha no Arquivo do Estado de São Paulo, Juízo de Órfãos. Inventários e testamentos, C00651-1746. Analisando as descrições das casas urbanas de tempo dos bandeirantes constantes da série Inventários e Testamentos, publicada pelo Departamento do Arquivo do Estado, Carlos Lemos comenta que lanço "significava uma série de cômodos encarreirados, um atrás do outro, formando uma fila perpendicular à rua ou ao terreiro, quando se tratava de casa rural". Cf. Carlos A. C. Lemos (1999, p. 24).

94. No Vocabulario Portuguez e Latino, o adjetivo "mistico" tem, como uma das definições: "diz-se de casas, vinhas \&c. quando dão humas nas outras, sem terem muro, ou cousa que o valha, que as separe"; cf. o volume 5 de Raphael Bluteau (1712-1728, p. 515). Disponível em: <http://www.brasiliana.usp.br/dicionario $>$ Acesso em 13 maio 2010.

95. Ver o registro relativo a Francisco Pereira Mendes no Arquivo do Estado de São Paulo, Juízo de Órfãos. Inventários e testamentos, C00664-1782

96. A expressão "recheio da casa" foi cunhada por Jorge Miguel Pedreira (1995, p 307), para referir-se aos bens domésticos que compreendiam mobiliário, roupa pessoal e da casa, louça, objetos de metal, imagens, oratórios.

97. Ver o registro relativo ao Brigadeiro Jordão, no Arquivo do Tribunal de Justiça do Estado de São Paulo, Inventários do $1^{10}$ cartório de família, proc. 229. 1828.

98. Ver o registro relativo a Joaquim Mariano Galvão de Moura Lacerda, no Arquivo do Tribunal de Justiça do Estado de São Paulo, Inventários do 1 o cartório de famí lia, proc. 721. 1834. Em nenhum dos inventários con- 
sultados para a elaboração deste artigo, na parte relativa à descrição dos bens de raiz, foi mencionada a existência de senzala e cavalariça.

99. Cf. o volume 3 de Eudes de Mello Campos Junior (1997, p. 430).

100. Cf. Nestor G. Reis (2004, p. 107-109).

101. Sobre a persistência das rótulas nas residências paulistanas ao longo do século XIX, ver Paulo C. Garcez Marins (1999, cap.3).

102. Cf. Nuno Madureira (1992, p. 155).

103. Cf. Francisco de C. Canto e Melo (1978, p. 428).

104. É fundamental enfatizar que as análises sobre aspectos da vida material do segmento mercantil foram empreendidas com base na leitura de apenas 10 inventários - 9 relativos aos personagens em questão e 1 aberto após o falecimento de Ana de Oliveira Montes, esposa de Jose Rodrigues Pereira. Embora a amostra seja bastante reduzida, conta a seu favor o fato de tratar-se de comerciantes proeminentes, unidos por laços de parentesco, residentes no centro da cidade de São Paulo.

105. A expressão sistema de travação foi cunhada por Nuno Madureira (1992, p. 165).

106. Idem, p. 176.

107. Idem, p. 178. Para a realidade portuguesa do primeiro quartel do século XIX, o autor havia analisado o papel dos tamboretes em relação as cadeiras, uma vez que aqueles já haviam deixado os mochos em segundo plano desde o início do século anterior. Para o caso paulistano, a situação é relativamente diferente, pois foram os tamboretes que deixaram de figurar nos inventários oito- descrita por sua alocação na varanda, nas oito salas, nos quartos de hóspedes e no escritório, estes últimos localizados no andar térreo -, a individuação dos aposentos é flagrante.

A interiorização das sociabilidades nesse contexto pode ser constatada, por exemplo, pelo número vertiginoso de móveis de assento ou descanso existentes no espaço doméstico. Nos três inventários abertos entre as décadas de 1820/1830, a quantidade variou entre 51,81 e 215 peças, estas últimas avaliadas na residência do brigadeiro. Dado o conforto proporcionado aos convivas, não admira que Francisco de Castro Canto e Melo, responsável pela descrição da viagem do príncipe regente a São Paulo em 1822, tenha se impressionado com a recepção dada pelo brigadeiro Jordão a D. Pedro, qualificando-a como "obsequiosa e magnífica hospedagem" 103.

Nessa residência, os móveis de assento estavam distribuídos em mochos, cadeiras, escabelo, bancos, canapés, sofás. Interessante perceber que estes dois últimos artefatos, estreantes nos inventários do século XIX ${ }^{104}$, eram destinados ao uso coletivo.

A aplicação da palhinha preponderou nos assentos das cadeiras que, evidentemente, eram os móveis mais numerosos, atingindo 170 unidades. É bem provável que a redução do peso estrutural das cadeiras, pela adoção da palhinha como revestimento, aliado à linha curva das pernas, que dispensava o sistema de travação ${ }^{105}$, tenha sido um dos fatores para a difusão desse equipamento na primeira metade do século XIX. Leveza e agilidade desvinculavam a cadeira de uma posição rígida e definida, tornando-a uma peça flexível para situações de conversação, jogo, dança 106 .

Tais características aproximavam a cadeira do mocho, assento em geral sem espaldar - de palhinha, de sola picada, de madeira -, que ainda permanecia nas residências das grandes fortunas do primeiro quartel do século XIX, mas agora limitado a completar "os jogos de sala como se fosse satélite cujas órbitas só têm razão de ser graças à posição destacada das cadeiras" 107. Cada vez mais, estas passam a secundarizar os mochos, o que pode ser observado por suas descrições: mais inferiores, com assento furado.

Entretanto, não se pense que o revestimento de palhinha estivesse universalizado neste momento. No inventário de Joaquim José dos Santos, predominaram as cadeiras de sola picada, herdeiras dos modelos da segunda metade do século XVIII, totalizando 33 peças, aí incluídas as de campanha, cadeiras de pernas em tesoura, dobráveis, feitas em forma de móvel rústico ${ }^{108}$, cuja ligeireza contrastava com a robustez daquelas de sola lque podia ser crua ou curtida, lisa ou decorada). O couro era fixado, nas bordas do assento e nas prumadas do encosto, por meio de pregaria de latão 109 .

Ainda que em número menor do que as avaliadas nas primeiras décadas do século XIX, as cadeiras presentes nos inventários abertos nas décadas de 1770-1780 compunham, em geral, um conjunto de seis ou doze unidades. No inventário do alferes Manuel Rodrigues Jordão, por exemplo, aberto em 1786, os móveis de assento correspondiam a 12 cadeiras de pés de burro, de encosto e assento de sola, e 6 cadeiras de sola picada com pregaria. No inventário de 
Ana de Oliveira Montes, esposa de José Rodrigues Pereira, falecida em 1765, encontra-se um conjunto composto por 12 cadeiras de jacarandá com seus coxins à moderna, dois mochos e uma poltrona, irmãos das cadeiras ${ }^{110}$.

Para a compreender a descrição das peças em conjunto, realizada pelos avaliadores, pareceu-me apropriada a análise de Nuno Madureira, para o contexto português setecentista, de que a quantidade de cadeiras estava provavelmente ancorada na tradição decorativa e no sistema artesanal de produção e comercialização de mobiliário em Portugal, onde se enraizou o hábito de encomendar cadeiras para encher uma sala, seguindo o princípio convencional calculado na base da dúzia e da meia dúzia ${ }^{11}$. O fało de o número de cadeiras seguir tal princípio pode indicar o transplante do hábito lusitano para a colônia, e, não, uma antecipação da concepção - que passaria a vigorar no século XIX - desses móveis como mobília com uniformidade decorativa.

Para a reduzida amostragem aqui trabalhada, tal descrição de mobiliário é bastante inovadora, uma vez que, nos inventários da geração anterior, sequer uma cadeira foi avaliada, os móveis de assentos limitando-se aos mochos, tamboretes e tripeça.

Interessante observar que nenhuma das peças descritas no processo de Ana de Oliveira Montes foi legada ao marido, nem mesmo a poltrona que, por aparecer comumente isolada, imagina-se demarcar um espaço reservado, ser um assento pessoal, destinado muito provavelmente ao chefe da casa ${ }^{12}$. De toda sorte, como os herdeiros eram menores e residiam com o pai, o mobiliário permaneceu em sua residência.

Na verdade, ao viúvo, couberam um leito, um catre, uma papeleira e um espelho. Por tamanha escassez de mobiliário, vê-se que, naquele tempo, não se julgava uma pessoa pela casa, ainda mais se pensarmos que foi ele considerado - homem mais abastado da cidade de São Paulo pelo censo de 1765, desempenhando os mais altos cargos nos órgãos de poder local e - como já se disse - agraciado com a mercê de cavaleiro da Ordem de Cristo, conjugando capital mercantil e simbólico.

Uma boa medida para perceber investimentos realizados em reconhecimento social são os hábitos das ordens militares lançados nos bens dos inventários, já que eles eram exibidos em festividades, cerimônias públicas ou mesmo em momentos fúnebres. José Rodrigues Pereira, por exemplo, declara em testamento: "Meu corpo em qualquer parte que falecer será amortalhado no hábito de meu Padre São Francisco, levando por cima o hábito de minha Ordem de Cristo, de que sou também professo e será sepultado na capela de minha venerável Ordem Terceira da Penitência"113.

Para ter-se uma idéia da importância, para ele, das marcas sociais distintivas, basta dizer que possuía uma cruz de Cristo de pedras de granadas e com diamantes no valor de $9 \$ 600$, outra cruz grande com diamantes e granadas avaliadas em $32 \$ 000$ e uma pequena esmaltada de vermelho, de $\$ 700$, o que totalizava $42 \$ 300$, valor pouco menor do que a cifra de $53 \$ 440$ atingida pelos móveis que the couberam pela morte da esposa - o leito foi avaliado em $20 \$ 800$, a papeleira em 12\$800, o catre em $\$ 640$ e o espelho em $19 \$ 200$. centistas consultados. Entretanto, as conjunturas guardam aproximações estreitas se levarmos em conta o papel dos móveis com e sem espaldar.

108. Cf. Tilde Canti (1980, p. 153).

109. Idem, p. 111.

110. Ver o registro relativo a Ana de Oliveira Montes no Arquivo do Estado de São Paulo, Juízo de Órfãos. Inventários e testamentos, C00664-1765.

111. Cf. Nuno Madureira (1992, p. 158).

112. Idem, p. 161

113. Ver o registro relativo a José Rodrigues Pereira no Arquivo do Estado de São Paulo, Juízo de Órfãos. Inventários e testamentos, C00612-1770. 
114. Cf. Tilde Canti (1980, p. 129).

115. Ver o registro relativo a José Rodrigues Pereira no Arquivo do Estado de São Paulo, Juízo de Órfãos. Inventários e testamentos, C00612 1770.

116. Cf. Glória Bayeux (1997, p. 74).
O leito herdado, descrito como de jacarandá, com balaústres de roscas e cabeceira de latão, parece referir-se à cama mais larga, destinada ao casal, diferenciando-se do catre que deveria corresponder à cama de solteiro. Embora haja confusão no emprego dos termos, a conjugalidade parece ser a marca deste móvel de repouso, pois, na partilha dos bens de José Rodrigues Pereira, ocorrida seis anos depois, ele coube à única filha que estava casada na ocasião.

Outra informação de natureza diversa parece confirmar tal suposição. Manuel Mendes de Almeida, falecido na década de 1750, possuía um leito de jacarandá da Bahia e um catre feito na terra, ambos igualmente avaliados em $4 \$ 800$, o que sugere que a diferença entre os móveis deveria estar relacionada mais ao usuário do bem do que à qualidade da madeira e à ornamentação empregadas.

Ainda que o ato de dormir não estivesse nas preocupações de conforto durante o século XVIII, nos inventários desses comerciantes reinóis de avultada riqueza para a realidade local, os leitos aparecem desde meados do século com alguma ornamentação. Se a rede, própria para a mobilidade espacial, era o artefato para dormir usual no século XVII, iá no seguinte, os leitos passaram a ser mais utilizados, e sua principal característica era o emprego do torneado mais grosso 114 .

Tal transformação do mobiliário é patente no inventário de Manuel Mendes de Almeida. Embora duas redes ainda figurassem entre seus bens, o capitão-mor possuía quatro leitos de jacarandá da Bahia, torneados, com balaústres para sustentação da armação do dossel. Como se vê, o processo de fixação, dos negócios e de residência, na cidade de São Paulo encontrava contrapartida nesse mobiliário mais sólido e pesado que os agentes mercantis passavam a encomendar para suas moradias e legavam aos seus descendentes.

Uma estabilidade ainda maior poderia ser associada à possibilidade de se possuir um móvel específico para repouso diurno. Tal é o caso do preguiceiro, introduzido no mobiliário existente nos inventários abertos nas décadas de 1770-1780, em geral com cabeceira e assento de sola, como descrito no processo de José Rodrigues Pereira, "de jacarandá com sua cabeceira lavrada e assento de sola"115. Tal peça, no século seguinte, foi sendo gradualmente substituída pela marquesa, espécie de canapé largo, em geral com os braços de madeira altos terminando em volutas e assento de palhinha ${ }^{116}$. No inventário do brigadeiro Jordão, foram avaliadas duas marquesas, ambas de madeira com assento de sola. Tanto no processo dele como nos de seus contemporâneos, na relação do mobiliário de repouso noturno, passa a ser usado o termo cama, no lugar de leito.

O leito herdado por José Rodrigues Pereira foi para seu próprio uso, mas, muito provavelmente, a papeleira que the foi legada estava ligada a seus negócios particulares. Ainda que a vinculação direta - desse móvel de guarda - com a atividade profissional do proprietário não seja consenso, é praticamente impossível não reconhecê-lo como peça fundamental à lide mercantil, servindo para guardar e organizar, nos escaninhos e gavetas, documentos relativos às transações comerciais. Não bastasse tratar-se de uma amostra de comerciantes, 
o fato de existirem papeleiras nos inventários dos indivíduos de todas as gerações corrobora tal suposição.

No entanto, os móveis com gavetas não estavam aqui difundidos no século XVIII. Na verdade, o que predominava nos inventários desse período era o mobiliário de guarda com tampo de abrir, representado pelas arcas, caixas, canastras e baús. É legítimo supor que a intensa mobilidade espacial vivenciada pelos forasteiros reinóis falecidos no século XVIII, nas contínuas viagens ao Rio de Janeiro, em busca de mercadorias, e às áreas mineratórias, para o abastecimento das populações, tenha se refletido no apego aos baús ${ }^{17}$. Nos inventários abertos em meados do XVIII, era comum caracterizar baús e canastras como de carga, feitos, em geral, só de madeira ou revestidos de couro com pregaria.

Embora importados, ou confeccionados sob encomenda por oficiais mecânicos locais, tais artefatos eram praticamente os únicos exemplares de mobiliário disponíveis nos estabelecimentos comerciais existentes na cidade de São Paulo naquele período, como se constata pelos arrolamentos de fazenda seca de loja, presentes em espólios setecentistas. Mais curioso é que os registros de "sete baús de carga de moscóvia com suas fechaduras e um sem chave"118, ou de "um baú usado com duas fechaduras"119, ou ainda de "duas caixas de madeira [...] uma das quais é quebrada" ${ }^{20}$, evidenciam a oferta de bens usados aos consumidores, indicando a demanda por móveis de tal gênero, inclusive de segunda mão; o que, por sua vez, reforça a análise sobre seu emprego cotidiano na sociedade paulistana de outrora ${ }^{121}$.

Quando dispostos nas residências, neles poderiam ser encontrados enxovais, roupas, mantimentos, roupas, aviamentos em geral, armas, documentos, dinheiro ${ }^{122}$. Embora Manuel Mendes de Almeida, falecido em 1754, dispusesse de papeleira e contador, guardava pertences importantes numa caixa, assim descrita pelos avaliadores: feita nesta terra, com sua fechadura, onde estão os papéis do defunto inventariado e cartas, e tem seis palmos de comprido e dois de largo"123.

No entanto, tais móveis de guarda acompanharam o processo de sedimentação não só das famílias em questão como da própria sociedade paulistana. Ao longo do século XVIII, começaram a ganhar pés e gavetas, e perderam as argolas laterais, fixando-se como móveis de interiores ${ }^{124}$, tal como se constata no inventário de Francisco Pereira Mendes, aberto em 1781, em que uma caixa foi descrita como sendo grande, de duas gavetas por baixo, feita de jacarandá, na Bahia. Nos inventários dos anos de 1820-1830, ainda figuravam baús, caixas e canastras, mas deixaram de preponderar, sendo qualificados como inda em bom uso, ou velhos, ou usados.

Embora o armário só tenha aparecido nos inventários do século XIX consultados, nas gerações anteriores foram mencionados os guarda-roupas, que poderiam corresponder a armários grandes. Fechados por uma ou mais portas, a divisão interna composta por prateleiras e gavetas os aproximava dos móveis de guarda com tampo, pois aí também as vestimentas eram dispostas horizontalmente. Contudo, as afinidades não se encerravam no nível técnico. Do ponto de vista cultural, o armário partilhava com a arca e a caixa "a fisionomia maciça e austera,
117. "Além das funções desempenhadas na casa, o baú é o companheiro ideal quando se trata de partir em jornada. Para isso, basta refazer o seu conteúdo e certificar a solidez das fechaduras". Cf. Nuno Madureira (1992, p. 179).

118. Ver o registro relativo a Gaspar de Matos no Arquivo do Estado de São Paulo, Juízo de Órfãos. Inventários e testamentos, C00734-1735. No Vocabulario Portuguez e Latino, o vocábulo moscóvia (de Moscou, Rússia) foi definido como "couro que vem da Moscovia"; cf. o volume 5 de Raphael Bluteau (1712-1728, p. 596); e; no Diccionario da lingua portugueza, figura como "coiro cortido de cor roixa que vem de Moscovia"; cf. o volume 2 de Antonio de Moraes Silva (1813, p. 321). Disponíveis em: <http://www.brasiliana. usp.br/dicionario>. Acesso em 13 maio 2010.

119. Ver o registro relativo a José da Silva Ferrão no Arquivo do Estado de São Paulo, Juízo de Órfãos. Inventários e testamentos, C005411762.

120. Idem

121. Sobre a venda de matéria-prima e ferramentas para confecção de móveis na cidade de São Paulo durante a primeira metade do século XIX, ver Maria Lucília Viveiros Araújo (2004).

122. Cf. Carlos A. C. Lemos (2004, p. 187)

123. Ver o registro relativo a Manuel Mendes de Almeida no Arquivo do Estado de São Paulo, Juízo de Órfãos. Inventários e testamentos, C00532 1756.

124. Cf. Marlene Suano (1992, p. 16). 
125. Cf. Nuno Madureira (1992, p. 190)

126. Cf. Marlene Suano (1992, p. 18).

127. Cf. Nuno Madureira (1992, p. 186)

128. Ver o registro relativo a Manuel Rodrigues Jordão (brigadeiro), no Arquivo do Tribunal de Justiça do Estado de São Paulo, Inventários do $1^{\circ}$ cartório de família, proc 229. 1828

129. Cf. José de Almeida Santos (1963), apud Giselle M. L. Paixão (1999, p. 281). a resistência sem limites às transformações formais e a vocação familiar, unitária, não individual" 125, afastando-se, justamente por tais características, da cômoda e da papeleira.

A cômoda talvez tenha sido o móvel de guarda que, no espaço doméstico, simboliza de forma mais concreta a estabilidade na ordem socioeconômica, pelo emprego mais enfático das gavetas e o gradual desaparecimento das fechaduras. Mais do que isso, a divisão física de um espaço, até então uniforme e contínuo, indica a nova necessidade de se guardarem seletivamente os pertences ${ }^{126}$. Essa maior complexidade de itens em uso na casa corresponde, sem dúvida, a uma maior disponibilidade de excedente na economia, o que, no caso dos agentes mercantis aqui tratados, traduz-se pela riqueza acumulada e pelo destaque socioeconômico atingido na sociedade local.

Diferentemente das caixas e dos armários, a função da cômoda não era armazenar de tudo um pouco; ao contrário, a pequena área útil das gavetas indica que era necessário escolher o que se queria guardar. A própria localização do artefato (no quarto de dormir e/ou na sala de estar) reforça sua concepção como veículo de transmissão de dignidade ao patrimônio ${ }^{127}$.

As cômodas foram mais correntes nos inventários abertos no século XIX, e a ornamentação, presente em algumas descrições, sugere não só a preocupação com o aspecto exterior mas também sua exposição em ambientes frequentados por visitantes. No espólio do brigadeiro Jordão, por exemplo, encontramos três cômodas, duas delas descritas como "uma cômoda de madeira com seus embutidos e com duas gavetas, com assento de pedra", "uma cômoda de madeira, também com seus embutidos, e com duas gavetas e fechaduras, com assento de pedra e este quebrado"128. Os embutidos correspondem à composição ornamental por meio de técnica de marchetaria' 29 .

Nos espólios dos indivíduos da 3. a geração, os avaliadores também realçaram tal efeito decorativo em outros móveis presentes, em especial em mesas, cadeiras, canapés, caixas, meia-cômoda e cabeceiras de camas. Afora este último móvel, os demais estavam dispostos em ambientes propícios à recepção de visitas, o que sugere a crescente importância da visualidade nas primeiras décadas do século XIX.

Desde fins do século XVIII, as mesas mencionadas foram, aos poucos, substituindo os bufetes como móveis de suporte nas residências. Enquanto este último tinha aspecto austero e pesado, por vezes, ornamentado com pés torneados, ligados por travessas, as mesas adquiriram maior leveza, servindo como apoio para os vários conjuntos de assentos espalhados pelas salas abertas a um público maior. Para se ter uma idéia, no inventário do brigadeiro Jordão, para dar suporte aos 215 móveis de assento registrados, foram contabilizadas 51 mesas com as mais diversas características: grandes, pequenas, compridas, de madeira, de assento de pedra, de abrir, com e sem gavetas, de canto, com rodas nos pés, de chá, que servem para engomar, que servem para guardar bacia e outras coisas, forradas de pano. A difusão da mesa pelo espaço doméstico pode, inclusive, ser constatada no seu deslocamento para o quarto de dormir, servindo como banquinha de pé de cama. 
Se anteriormente, os bufetes serviam de suportes para oratórios, papeleiras e contadores, fazendo as vezes de mesas de servir ou de cozinha, raramente esses móveis eram usados para refeições ${ }^{130}$. Já nos inventários do século XIX, havia mesas destinadas exclusivamente para tal finalidade. Embora nesses processos ocorresse uma proliferação de móveis de apoio, as mesas de jantar eram em número bastante reduzido, revelando tanto a individuação do móvel permanente na sala de jantar, como a sedimentação - por meio dos ritos alimentares - de uma forma mais estável, coerente e integradora do núcleo familiar, separando-o dos escravos e outros eventuais corresidentes ${ }^{131}$. Mas não só. A fixação de mobiliário de sala de jantar é fator importante para a análise tanto das relações domésticas como da própria sociedade em questão, pois aponta para a consolidação da posição social de grupos mercantis enraizados, desde meados do século XVIII, na cidade de São Paulo, por meio dos negócios realizados.

Além disso, a informação, dada pelos avaliadores, de que as mesas de jantar presentes nas residências de Joaquim José dos Santos e de Joaquim Mariano Galvão de Moura Lacerda haviam sido confeccionadas com madeira da terra pode indicar o desenvolvimento de ofícios mecânicos na cidade de São Paulo, principalmente os ligados à marcenaria e à carpintaria, no primeiro quartel do século XIX, corroborando estudos sobre o crescimento do setor secundário neste período ${ }^{132}$. Tal hipótese ganha maior sustentação quando se verifica que, nos inventários consultados, era incomum haver registro sobre a procedência dos móveis, existindo tão somente anotação sobre o material empregado. No caso dos processos das gerações falecidas nas décadas de 1820-1830, imperam as menções aos artefatos feitos na terra ${ }^{133}$, diferentemente do que constava nos de seus antepassados, que mandavam vir - embora poucos - móveis da Bahia, em especial leitos e bufetes de jacarandá.

Entretanto, ainda que tenham ocorrido significativas transformações no espaço doméstico, o interior da casa não bastava para conferir dignidade social ao seu proprietário. Essa poderia evidenciar-se pela posse de móveis utilizados para o transporte de pessoas. Nesse sentido, o mobiliário representado pelos veículos terrestres arrolados nos inventários pode dar a medida da importância da apresentação pessoal em sociedade e, ainda, indicar que a aparição pública ocorria mediante a transposição do ambiente doméstico para o espaço urbano ${ }^{134}$.

As cadeirinhas de arruar, usadas para transporte nas cidades, eram carregadas por dois escravos, um à frente e outro atrás. Embora o indivíduo, conduzido sentado, estivesse protegido por quatro paredes, podia espiar o entorno e mostrar-se aos transeuntes quando o desejasse, bastando para isso lançar mão dos mesmos procedimentos utilizados em casa, ou seja, abrir as cortinas que guarneciam as janelas. Caso não quisesse se expor, a ornamentação personalizada do veículo e os trajes dos serviçais davam conta de comunicar que seu proprietário estava saindo às ruas.

Nos processos do brigadeiro Jordão e do coronel Joaquim José dos Santos, para além da função de locomoção, os bens avaliados podem ser tomados como sinais ostentatórios de riqueza e de bom gosto. $\bigcirc$ primeiro tinha uma
130. Cf. Tilde Canti (1980, p. 137).

131. Cf. Nuno Madureira (1992, p. 205).

132. Embora com números díspares, ver os trabalhos de Maria Luiza Marcílio (2000) e Elizabeth Anne Kuznesof (1986).

133. Apenas um conjunto de sofá e cadeiras, pertencente a Joaquim Mariano de Moura Lacerda, era madeira do Rio de Janeiro; e uma meia-cômoda e uma mesa eram feitas de "madeira de fora", sem que houvesse especificação sobre a origem.

134. Cf. Heloisa Barbuy (2000, p. 10-11). 
135. Idem, p. 15.

136. Ver o registro relativo a Joaquim Mariano Galvão de Moura Lacerda, no Arquivo do Tribunal de Justiça do Estado de São Paulo, Inventários do 1 o cartório de família, proc. 721.1834. cadeirinha, com seus dourados e com cortinados de pano verde; já o segundo possuía duas cadeirinhas - uma toda dourada, com seus cortinados de veludo lavrado, forrada de damasco amarelo; e outra, com seus dourados, e com cortinas de pano azul ordinário.

Joaquim Mariano Galvão de Moura Lacerda, por sua vez, era detentor de veículos movidos por tração animal. Para o transporte urbano, dispunha de duas traquitanas, também denominadas carruagens, de quatro rodas, guiadas por um condutor. A mais nova-envidraçada - poderia ser considerada como a sala de visitas portátil. Entretanto, para vencer os percursos mais longos, que levavam à sua morada de casas na vila de São Carlos e às fazendas em Piracicaba e Araraquara, é provável que o marechal de campo lançasse mão de cavalos e das duas liteiras de que dispunha, puxadas por burros ou mulas, um à frente e outro atrás, estes conduzidos por escravos.

Como os avaliadores se restringiram a descrevê-las com cortinas de pano anil e com arreios, ignora-se se correspondiam aos modelos mais antigos, destinados a levar uma pessoa deitada ou reclinada sobre almofadas, ou aos mais luxuosos, que tinham assentos e permitiam o transporte de duas pessoas sentadas, uma de frente para outra ${ }^{135}$. Arrolado na sequência dos veículos, o mobiliário de guarda, iá gasto - "um caixão muito grande de guardar mantimento com vários repartimentos, porém muito velho", "um par de canastras, cobertas de sola, com suas competentes ferragens" e "rrês pares das ditas canastras, todas cobertas de couro e já velhas" 136 -, evidencia que as jornadas eram constantes, envolvendo muito mais gente, animais e carregações do que as duas liteiras deixavam entrever.

Se no início do século XIX estava em curso uma nova realidade nas formas de morar, na concepção dos interiores domésticos e na do espaço urbano, essa foi vivenciada pelos personagens aqui apresentados, que, como homens de seu tempo, passaram a dispor em suas moradas de artefatos portadores e promotores de distinção social, bem ao gosto da economia de prestígio vigente na sociedade de então. Nesse sentido, vale reforçar que, paralelamente ao sucesso econômico, todos os sujeitos abordados haviam participado de instituições de poder local, garantindo reconhecimento social.

De forma análoga, alguns membros das famílias em questão, pertencentes às gerações seguintes, procuraram conjugar os preceitos sociais e materiais, forjados no bojo do império brasileiro, com a tradicional aquisição de títulos nobiliárquicos e, ainda, encontraram na endogamia parental o sustentáculo para sua afirmação social.

A persistência das ligações parentais ao longo do século XIX

Corroborando este viés analítico, o diagrama apresenta uma última geração, falecida na década de 1870, que, além de destacar-se no cenário econômico paulista, teria atuado na políitica imperial. 
Joaquim José dos Santos Silva, ele próprio fruto da ligação das famílias de Manuel Veloso e Manuel Mendes de Almeida, casou-se, em primeiras núpcias, com a prima, bisneta paterna de Mendes de Almeida e bisneta materna de Manuel José da Cunha ${ }^{137}$. Sua propriedade mais célebre foi a Chácara do Chá, obtida por herança do tio paterno Francisco Xavier dos Santos, localizada no também chamado Morro do Chá. Foi agraciado com o título de barão de Itapetininga em $1863^{138}$

Sua filha casou-se com o primo Amador de Camargo Lima, futuro barão de São João do Rio Claro, fruto da união das famílias de Manuel Veloso e de Manuel José da Cunha ${ }^{139}$. Em 1848, o barão herdou da mãe a gleba denominada Laranja Azeda, que pertenceu à sesmaria do Morro Azul. Nesse ano, fundou a fazenda Santa Gertrudes, iniciando um engenho de açúcar e, depois, cultivando café. Por volta de 1870, a fazenda viria a tornar-se uma das maiores de São Paulo, assim como a fortuna de seu proprietário ${ }^{140}$.

Para finalizar a apresentação dos componentes do diagrama, destaca-se o primo do barão de São João do Rio Claro e sobrinho do brigadeiro Jordão, Antonio da Silva Prado, o barão de lguape. Esteve envolvido com a arrematação de contratos de cobrança de impostos, em especial, daqueles que incidiam sobre os animais em trânsito para Sorocaba; foi negociante de açúcar, animais e gêneros variados; temporariamente, foi senhor de engenho em Jundiaí e, finalmente, banqueiro, tornando-se um dos paulistas mais abastados de seu tempo ${ }^{141}$.

Se os trabalhos historiográficos tornaram conhecidas do público as trajetórias dos barões aqui referidas e, inclusive, elas se encontram disseminadas em obras de divulgação sobre os grandes personagens da história paulista e do Império, poucos são, no entanto, os que têm conhecimento de suas ascendências. Tal falta de informação ocorre muito em função do silêncio dos linhagistas quanto às origens mecânicas de seus antepassados ${ }^{142}$. Embora os nomes figurem nas obras genealógicas, avós e bisavós são identificados pela riqueza, pelo destaque na esfera política e pelas patentes das companhias de ordenanças, mas muito raramente pelas ligações estreitas com a lide mercantil. Daí, os comerciantes ativos em solo piratiningano no século XVIII ficarem relegados ao esquecimento - e a própria cidade, nesse período, associada ao vazio populacional, à decadência e à penúria.

De forma diversa, pretendo sugerir, com esta pesquisa, outra perspectiva de análise, em que os agentes mercantis reinóis que se fixaram na cidade de São Paulo ao longo do século XVIII assumem o papel de protagonistas, justamente em razão das transações comerciais e do sucesso no mundo dos negócios.
137. Cf. o volume 8 de Luiz Gonzaga da S. Leme (1905, p. 171)

138. Disponível em: <www. almanack.paulistano.nom. br/barao\%20itapetininga. html>. Acesso em 13 maio 2010.

139. Cf. Frederico de B. Brotero (1948, p. 550).

140. Disponível em: <www. fazendasantagertrudes.com br/conteudo.asp?pag= historico_dir.html>. Acesso em 13 maio 2010

141. Ver Maria Thereza S. Petrone (1976).

142. Sobre o ocultamento de informações que poderiam comprometer membros da elite paulista, em razão de condutas morais consideradas "impróprias", ver Paulo C. G. Marins (2002, p. 43-60). 


\section{REFERÊNCIAS}

\section{DOCUMENTAÇÃO PRIMÁRIA}

\section{Manuscrita}

Arquivo do Estado de São Paulo

\section{Inventários e testamentos}

Ana de Oliveira Montes: Juízo de Órfãos. Inventários e testamentos, C00664-1765.

Francisco Pereira Mendes: Juízo de Órfãos. Inventários e testamentos, C00664-1782.

Gaspar de Matos: Juízo de Órfãos. Inventários e testamentos, C00734-1735.

José da Silva Ferrão: Juízo de Órfãos. Inventários e testamentos, C00541-1762.

José Rodrigues Pereira: Juízo de Órfãos. Inventários e testamentos, C00612-1770.

Manuel José da Cunha: Juízo de Órfãos. Inventários e testamentos, C00651-1746.

Manuel Mendes de Almeida: Juízo de Órfãos. Inventários e testamentos, C00532-1756.

Manuel Mendes de Almeida: Juízo dos Resíduos. C05470, doc. 005.

Manuel Rodrigues Jordão: Juízo de Órfãos. Inventários e testamentos, C00652-1786.

Manuel Veloso: Juízo Ordinário. Inventários e testamentos, C00528-1752.

Maços de população

Maços de população, 1798. Disponível em <www.arquivoestado.sp.gov.br/viver/res_frameset.p hp?ident=032_020\&img=032_020_001.jpg>. Acesso em 13 mai. 2010.

Sesmarias, patentes e provisões

Sesmarias, patentes e provisões, livro 2 , f. $142 \mathrm{v}$.

Sesmarias, patentes e provisões, livro 3, - f. 14.

Sesmarias, patentes e provisões, -livro $5, \mathrm{f} .7 \mathrm{v}$.

Arquivo do Tribunal de Justiça do Estado de São Paulo

Inventários e testamentos

Joaquim José dos Santos: Inventários do $1^{\circ}$ cartório de família, proc. 427-1828.

Joaquim Mariano Galvão de Moura Lacerda: Inventários do $1^{\circ}$ cartório de família, proc. 721-1834.

Manuel Rodrigues Jordão (brigadeiro): Inventários do $1^{\circ}$ cartório de família, proc. 229-1828.

Arquivo da Cúria Metropolitana de São Paulo

Dispensas e processos matrimoniais

Francisco Pereira Mendes: Dispensas e processos matrimoniais, 4-44-270. 1749.

Inácio da Costa de Siqueira: Dispensas e processos matrimoniais, 4-11-67. 1739.

Joaquim José dos Santos: Dispensas e processos matrimoniais, 6-23-1881. 1789.

José Rodrigues Pereira: Dispensas e processos matrimoniais, 4-29-174. 1745.

Manuel Antonio de Araújo: Dispensas e processos matrimoniais, 5-52-1261. 1777.

Manuel José da Cunha: Dispensas e processos matrimoniais, 4-4-18. 1733.

Manuel Rodrigues Jordão: Dispensas e processos matrimoniais, 5-13-801. 1767.

Tomé Rabelo Pinto: Dispensas e processos matrimoniais, 4-4-18. 1733. 
Processos de divórcio e nulidade de casamento

Gregório de Castro Esteves: Processos de divórcio e nulidade de casamento, 15-1-3. 1729.

Registros de casamento

Lopo dos Santos Serra: Registros de casamento, Catedral da Sé, livro 2, 1690-1767, 1-3-16, f.108, 1739.

Livro das eleições e dos inventários da fábrica da Irmandade do Santíssimo Sacramento.

Instituto dos Arquivos Nacionais da Torre do Tombo

Habilitações da Ordem de Cristo

José Rodrigues Pereira: Habilitações da Ordem de Cristo, letra J, maço 24, n. 2, 1763.

Francisco Pereira Mendes: Habilitações da Ordem de Cristo, letra F, maço 4, n. 7, 1749.

\section{Impressa}

ABREU, Manuel Cardoso de. Divertimento admirável para historiadores observarem as machinas do mundo reconhecidas nos sertões da navegação das minas de Cuyabá e Matto Grosso. Oferecido ao Ilmo. e Exmo. Senhor Martinho de Mello e Castro, do Conselho de Sua Magestade e Secretário de Estado da Repartição da Marinha e Domínios Ultramarinos (1783). In: CLETO, Marcelino Pereira et al. Roteiros e notícias de São Paulo colonial: 1751-1804. São Paulo: Governo do Estado, 1977. p. 53-87.

ACTAS da Camara Municipal de S. Paulo, 8. São Paulo: Typographia Piratininga, 1916.

ACTAS da Camara Municipal de S. Paulo, 9. São Paulo: Typographia Piratininga, 1916.

ACTAS da Camara da Cidade de S. Paulo, 10. São Paulo: Typographia Piratininga, 1916.

ACTAS da Camara Municipal de S. Paulo, 11. São Paulo: Typographia Piratininga, 1916.

ACTAS da Camara Municipal de S. Paulo, 12. São Paulo: Typographia Piratininga, 1918.

ACTAS da Camara Municipal de S. Paulo, 13. São Paulo: Typographia Piratininga, 1918.

ANAIS da Biblioteca Nacional do Rio de Janeiro, v. 62. Rio de Janeiro: Ministério da Educação, 1940.

BLUTEAU, Raphael. Vocabulario portuguez \& latino: aulico, anatomico, architectonico... Coimbra: Collegio das Artes da Companhia de Jesus, 1712-1728. 8v.

COLEÇÃO Alberto Penteado de leis, decretos e alvarás. Acervo de Obras Raras do Museu Paulista/ USP, 0.792 .

DOCUMENTOS Interessantes para a História e Costumes de S. Paulo, 41. São Paulo: Typographia Andrade \& Mello, 1902.

DOCUMENTOS Interessantes para a História e Costumes de S. Paulo. São Paulo: Instituto Historico e Geographico de S. Paulo, v. 62, 1937.

DOCUMENTOS Interessantes para a História e Costumes de S. Paulo. São Paulo: Instituto Historico e Geographico de S. Paulo, v. 73, 1952.

MELO, Francisco de Castro Canto e. Descrição da viagem do príncipe do Rio de Janeiro a São Paulo, feita pelo gentil-homem de sua câmara Francisco de Canto e Melo. In: MORAES, A. J. M. 
História do Brasil-Reino e Brasil-Império. Belo Horizonte: Itatiaia; São Paulo: Edusp, 1978. p. 428-432.

REGISTO Geral da Camara Municipal de S. Paulo. São Paulo: Typographia Piratininga, v. IV, 1917.

SAINT-HILAIRE, Auguste de. Viagem à Província de São Paulo. Belo Horizonte: Itatiaia; São Paulo: Edusp, 1976

SILVA, Antonio de Moraes. Diccionario da lingua portugueza, recompilado dos vocabularios impressos ate agora, e nesta segunda edição novamente emendado e muito acrescentado. Lisboa: Typographia Lacerdina, 1813.

LIVROS, REVISTAS E TESES

ABUD, Kátia Maria. Autoridade e riqueza. Contribuição para o estudo da sociedade paulistana na segunda metade do século XVIII. 1978. Dissertação (Mestrado em História Social) - Faculdade de Filosofia, Letras e Ciências Humanas, Universidade de São Paulo, São Paulo, 1978.

ARAÚJO, Maria Lucília Viveiros de. Os interiores domésticos após a expansão da economia exportadora paulista. Anais do Museu Paulista, São Paulo, v. 12, p. 129-160, jan.-dez. 2004.

Os caminhos da riqueza dos paulistanos na primeira metade do oitocentos. São Paulo: Hucitec;Fapesp, 2006.

BARBUY, Heloisa. Veículos terrestres: dossiê. São Paulo: Serviço de Objetos do Museu Paulista-USP, 2000.

A cidade-exposição: comércio e cosmopolitismo em São Paulo, 1860-1914. São Paulo: Edusp, 2006.

BAYEUX, Glória. O móvel da casa brasileira. São Paulo: Museu da Casa Brasileira, 1997.

BELLOTTO, Heloisa Liberalli. Autoridade e conflito no Brasil colonial: o governo do Morgado de Mateus em São Paulo (1765-1775). 2. ed. São Paulo: Alameda, 2007.

BORREGO, Maria Aparecida de Menezes. A teia mercantil: negócios e poderes em São Paulo colonial (1711-1765). São Paulo: Alameda/ FAPESP, 2010.

BROTERO, Frederico de Barros. A família Jordão e seus afins. São Paulo: [s.n.], 1948.

BUENO, Beatriz Picolloto Siqueira. Tecido urbano e mercado imobiliário em São Paulo: metodologia de estudo com base na décima urbana de 1809. Anais do Museu Paulista, São Paulo, v. 13, n. 1, p. 59-97, jan.-jun. 2005

CANABRAVA, Alice P. Uma economia de decadência: os níveis de riqueza na capitania de São Paulo, 1765/67. Revista Brasileira de Economia. Rio de Janeiro, 26 (4), out./dez. 1972.

CAMPOS JUNIOR, Eudes de Mello. Arquitetura paulistana sob o Império: aspectos da formação da cultura burguesa em São Paulo. Tese (Doutorado em Arquitetura e Urbanismo) - Faculdade de Arquitetura e Urbanismo, Universidade de São Paulo, São Paulo, 1997, 4v.

CANTI, Tilde. O móvel no Brasil: origens, evolução e características. Rio de Janeiro: Cândido Guinle de Paula Machado, 1980. 
ELLIS JUNIOR, Alfredo. A economia paulista no século XVIII: ciclo do muar, ciclo do açúcar. São Paulo: Academia Paulista de Letras, 1950.

FLORY, Rae Jean Dell. Bahian society in the midcolonial period: the sugar planters, tobacco growers, merchants and artisans of Salvador and the Reconcavo, 1680-1725. Tese (Doutorado em História) - History Department, University of Texas, Austin, 1978.

KUZNESOF, Elizabeth Anne. The role of merchants in the economic development of São Paulo: 1765-1850. Hispanic American Historical Review, Durham, v. 60, p. 571-592, Nov. 1980.

1986.

Household economy and urban development: São Paulo, 1765 to 1836. Boulder: Westview,

LEME, Luiz Gonzaga da Silva. Genealogia paulistana. São Paulo: Duprat, 1903-1905. 10v.

LEME, Luiz Gonzaga da Silva. Genealogia paulistana (cd-rom). São Paulo: Macromedia, 2002.

LEME, Pedro Taques de Almeida Paes. Nobiliarquia paulistana histórica e genealógica. 5. ed. Belo Horizonte: Itatiaia; São Paulo: Edusp; 1980. 3v.

LEMOS, Carlos. A. C. Casa paulista: história das moradias anteriores ao ecletismo trazido pelo café. São Paulo: Edusp, 1999.

Notas sobre a cultura material e o cotidiano em São Paulo dos tempos coloniais. In: FERNANDES, P. P. (org.). História da Cidade de São Paulo, 1: A cidade colonial. São Paulo: Paz e Terra, 2004a. p. 179-189.

Organização urbana e arquitetura em São Paulo dos tempos coloniais. In: FERNANDES, P. P. (org.). História da Cidade de São Paulo, 1: A cidade colonial. São Paulo: Paz e Terra, 2004b. p. $145-177$.

LUNA, Francisco Vidal; KLEIN, Herbert. Evolução da sociedade e economia escravista de São Paulo, de 1750 a 1850. São Paulo: Edusp, 2005.

MADUREIRA, Nuno Luís. Cidade: espaço e quotidiano (Lisboa 1740-1830). Lisboa: Horizonte, 1992.

MARCíliO, Maria Luiza. A cidade de São Paulo. Povoamento e população. 1750-1850. São Paulo: Pioneira;Edusp, 1974.

Crescimento demográfico e evolução agrária paulista, 1700-1836. São Paulo: Hucitec;Edusp, 2000.

MARINS, Paulo César Garcez. Através da rótula: sociedade e arquitetura urbana no Brasil, séculos XVII a XX. Tese (Doutorado em História Social) - Faculdade de Filosofia, Letras e Ciências Humanas, Universidade de São Paulo, São Paulo, 1999, 2v.

. Mulheres de elite, filhos naturais. São Paulo, séculos XVIII e XIX. In: FUKUI, L. (Org.). Segredos de família. São Paulo: Annablume; Nemge/USP; Fapesp, 2002, p. 43-60.

MARQUES, Manuel Eufrasio de Azevedo. Apontamentos históricos, geográficos, biográficos, estatísticos e noticiosos da Província de São Paulo, seguidos da cronologia dos acontecimentos mais notáveis desde a fundação da Capitania de São Paulo até o ano de 1876. São Paulo: Martins, 1954. 2v.

MENESES, Ulpiano Toledo Bezerra de. Museus históricos: da celebração à consciência histórica. In: MUSEU PAULISTA. Como explorar um museu histórico. São Paulo: MP-USP, 1992. p. 7-10. 
NAZZARI, Muriel. O desaparecimento do dote: mulheres, famílias e mudança social em São Paulo, Brasil, 1600-1900. Trad. Lólio Lourenço de Oliveira. São Paulo: Companhia das Letras, 2001.

OLIVEIRA, Cecília Helena de Salles. A Independência e a construção do Império. São Paulo: Atual, 1995.

. Como funciona o Museu Paulista. In: MUSEU PAULISTA. Por dentro do nosso museu. São Paulo: MP-USP, 2005.

ORTMANN, Adalberto. História da antiga capela da Ordem Terceira da Penitência de São Francisco em São Paulo. Rio de Janeiro: Ministério da Educação e Saúde-DPHAN, 1951.

OSÓRIO, Helen. O império português no sul da América: estancieiros, lavradores e comerciantes. Porto Alegre: Editora da UFRGS, 2007.

PAIXÃO, Giselle Marques Leite. Sistema descritivo para acervos de mobiliário, contendo 923 vocábulos e 638 ilustrações. BARBUY, Heloisa (Org.). Instrumento para catalogação produzido para o Serviço de Objetos do Museu Paulista-USP. São Paulo: MP-USP, 1999.

PEDREIRA, Jorge M. V. Os homens de negócio da praça de Lisboa de Pombal ao vintismo (1755-1822). Tese (Doutorado em História) - Universidade Nova de Lisboa, Lisboa, 1995.

PETRONE, Maria Thereza Schorer. A lavoura canavieira em São Paulo: expansão e declínio (1765-1851). São Paulo: Difel, 1968.

. O barão de Iguape. São Paulo: Nacional, 1976.

PRADO JUNIOR, Caio. Evolução política do Brasil e outros estudos. 9.. ed. São Paulo: Brasiliense, 1975.

PRADO, Paulo. Paulística etc. 4. ed. São Paulo: Companhia das Letras, 2004.

RABELLO, Elizabeth Darwiche. D. As elites na sociedade paulista da segunda metade do século XVIII. São Paulo: Safady, 1980.

REIS FILHO, Nestor Goulart. São Paulo: vila-cidade-metrópole. São Paulo: Prefeitura de São Paulo, 2004.

SANTOS, José de Almeida. Mobiliário artístico brasileiro. São Paulo: Museu Paulista, 1963, 2v.

SOCOLOW, Susan. Los mercaderes de Buenos Aires virreinal: familia y comercio. Buenos Aires: Flor, 1991.

SUANO, Marlene. Alfaias, apetrechos, tarecos, trecos: os móveis. In: MUSEU PAULISTA. Como explorar um museu histórico. São Paulo: Museu Paulista-USP, 1992. p. 15-18.

TAUNAY, Affonso. de Escragnolle. Pedro Taques e seu tempo. São Paulo: Imprensa Oficial, 1923.

TOLEDO, Benedito Lima de. O Triângulo e a configuração de suas ruas e largos. In: INSTITUTO MOREIRA SALLES (Org.). Cadernos de Fotografia Brasileira. São Paulo: 450 anos. 2. ed. Rio de Janeiro: Instituto Moreira Salles, 2004. p. 360-380.

2007. São Paulo: três cidades em um século. 4. ed. rev. São Paulo: Cosac Naify; Duas Cidades, 


\section{SITES CONSULTADOS}

<www.almanack.paulistano.nom.br/barao\%20itapetininga.html>.

<www.arquivoestado.sp.gov.br/viver/res_frameset.php?ident=032_020\&img=032_020_001.jpg.>. (Refere-se aos Maços de população (1798), existentes no Arquivo do Estado de São Paulo.)

$<$ www.brasiliana.usp.br/dicionario $>$.

<www.fazendasantagertrudes.com.br/conteudo.asp?pag=historico_dir.html>.

Artigo apresentado em 11 /2009. Aprovado em 5/2010. 